UCRL-ID-155032

\title{
Nonradiological Environmental Report Maamora Site, Morocco
}

\author{
Paris E. Althouse, lead author LLNL \\ Richard G. Blake, coauthor LLNL \\ Dr. Bryan B. Bandong, coauthor LLNL \\ Hatim Belghit, coauthor CNESTEN \\ Nabil Dehbi, coauthor CNESTEN
}

\section{August 5, 2003}


This work was performed under the auspices of the U. S. Department of Energy by the University of California, Lawrence Livermore National Laboratory under Contract No. W-7405-Eng-48.

\section{DISCLAIMER}

This document was prepared as an account of work sponsored by an agency of the United States Government. Neither the United States Government nor the University of California nor any of their employees, makes any warranty, expressed or implied, or assumes any legal liability or responsibility for the accuracy, completeness, or usefulness of any information, apparatus, product, or process disclosed, or represents that its use would not infringe privately owned rights. Reference herein to any specific commercial product, process, or service by trade name, trademark, manufacturer, or otherwise, does not necessarily constitute or imply its endorsement, recommendation, or favoring by the United States Government or the University of California. The views and opinions of authors expressed herein do not necessarily state or reflect those of the United States Government or the University of California, and shall not be used for advertising or product endorsement purposes. 


\section{Nonradiological Environmental Report Maamora Site, Morocco}

The United States Department of Energy (USDOE) and National Nuclear Security Administration (NNSA)Lawrence Livermore National Laboratory for

The Moroccan National Center for Nuclear Energy Sciences and Techniques (CNESTEN)

$$
\text { July 17, } 2003
$$

Paris E. Althouse, lead author LLNL Richard G. Blake, co-author LLNL Dr. Bryan B. Bandong, co-author LLNL Hatim Belghit, coauthor CNESTEN Nabil Dehbi, coauthor CNESTEN 


\section{Table of Contents}

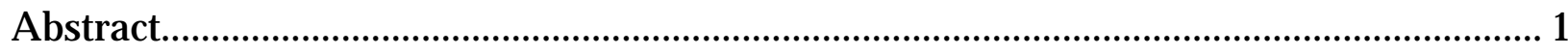

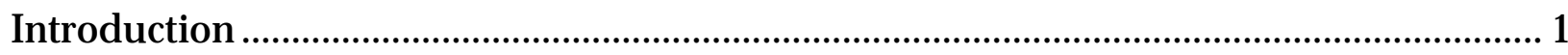

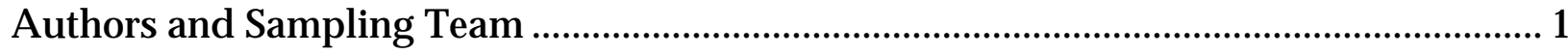

General Sampling Procedure …………………………................................................... 2

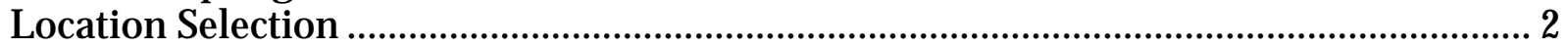

Soil Sampling Protocol .................................................................................................... 2

Short-lived Vegetation Sampling Protocol............................................................................. 3

Long-lived Vegetation Sampling Protocol ............................................................................ 3

Sample Shipment and Processing............................................................................ 5

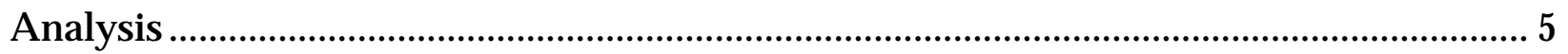

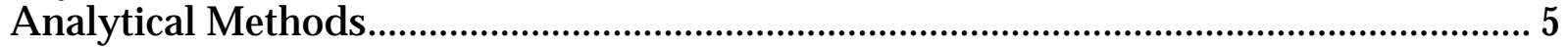

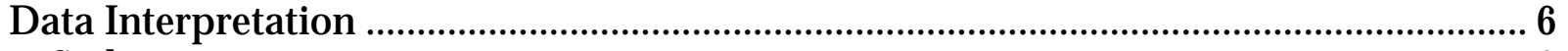

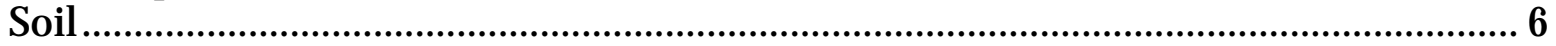

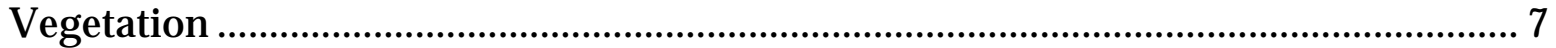

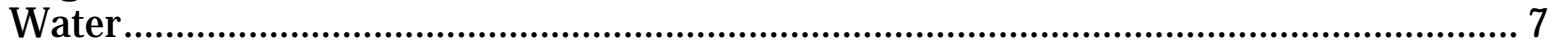

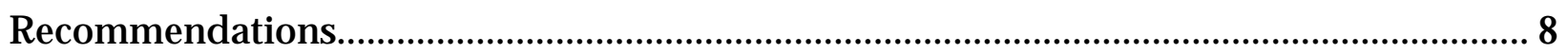

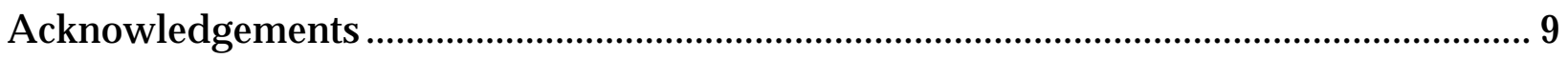

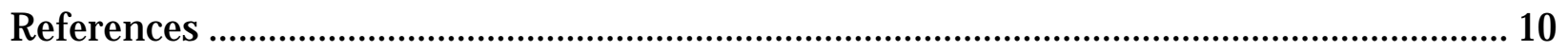




\section{List of Graphics, Tables, and Attachment}

Map 1. CNESTEN Site and sampling locations ......................................................... 11

Map 2. On site CNESTEN Sampling Locations ............................................................. 12

Photo 1. Soil sampling ..................................................................................................... 13

Photo 2. Sample documentation and collection of short-lived vegetation...................... 14

Photo 3. Long-lived vegetation (cork oak) collection .................................................... 15

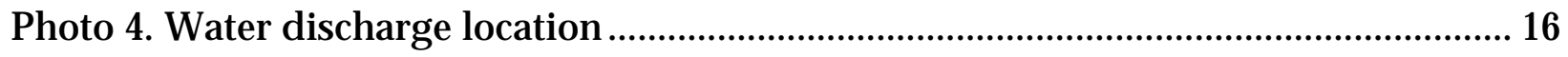

Photo 5. Location SE04, paint shack .............................................................................. 17

Photo 6. Sampling Team with Ms. Soufi, Mr. Al Hilali and Charafat Afailal................. 17

Table 1. Sampling locations and field notebook data ................................................... 18

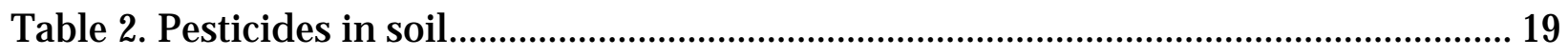

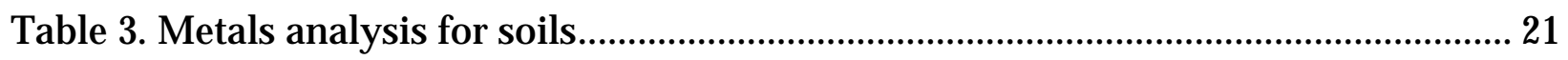

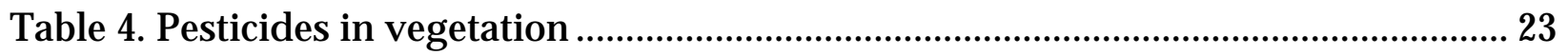

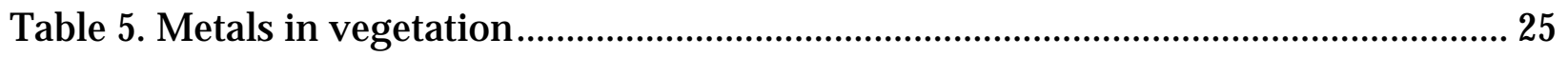

Table 6. Number of metal detections in soils and vegetation........................................ 27

Table 7. NPDES metals analysis in water ................................................................. 28

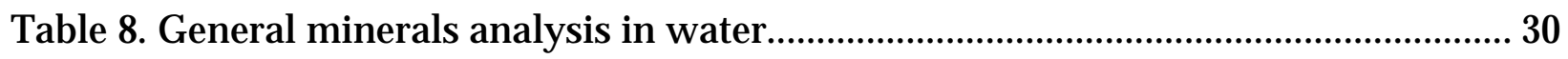

Table 9. Semivolatile organic compounds................................................................... 32

Chart 1. Metals in short-lived and long-lived vegetation and soils co-located samples 33

Attachment 1. Appendix A of EPA 540/R95/128, Soil Screening Guidance: Technical Background Document, May 1996 


\section{Abstract}

Under the Sister Laboratory Arrangement between Lawrence Livermore National Laboratory (LLNL) and the Moroccan National Center for Nuclear Energy Sciences and Techniques (CNESTEN), environmental sampling and analysis were performed to assess the background concentrations of nonradiological constituents in various environmental media at the Maamora Forest CNESTEN Laboratory Site.

Samples were collected from surface soil, surface water and groundwater wells, shortlived vegetation (mainly native grass), and long-lived vegetation (cork oak). Samples were collected inside the property fence line, in the buffer zone surrounding the site, and off site at water locations. The soil and vegetation samples were analyzed for metals and pesticides and screened for polychlorinated biphenyls (PCBs); the water samples were analyzed for metals, general minerals, and pesticides and screened for PCBs.

\section{Introduction}

The Maamora site is located in northwestern area of Morocco between Rabat and Kenitra, approximately 8 kilometers inland from the Atlantic Ocean. The rural site is easily accessible and surrounded by cork oak in the Maamora Forest (see Map 1 for a map of the project area). At the time of sampling much of the physical construction of the buildings and laboratories was completed; however, no construction had begun in the area zoned for the research reactor.

This report details the sampling conducted July 2-5, 2002 that was designed to determine the background or baseline concentrations of National Pollution Discharge Emission Standard (NPDES) metals, general minerals, and semivolatile organic compounds, including pesticides detected in various media on and around the site. This data may be used to provide the baseline concentrations for the analytes measured.

\section{Authors and Sampling Team}

The sampling team included the following LLNL and CNESTEN staff members.

\section{LLNL}

Richard Blake, Certified Geologist for Environmental Protection Department

Dr. Bryan Bandong, Program Leader for Chemistry and Environmental Services

Paris Althouse, Environmental Analyst for Environmental Protection Department

\section{CNESTEN}

Hatim Belghit, Sampling and Analysis Team Environmental Protection Department

Nabil Dehbi, Sampling and Analysis Team Environmental Protection Department 


\section{General Sampling Procedure}

\section{Location Selection}

To determine sample locations, the site was divided into four quadrants. From each quadrant, three locations were selected using a stratified random approach. Samples are identified in tables as the quadrant (NW, NE, SW, SE), a number $(01,02,03)$ and the sample type (SL-VG, LL-VG, SO, OW). Exceptions to this random selection process are identified below.

For soils and short-lived vegetation (e.g. grasses), the LLNL team selected sample locations that appeared to have the least amount of ground disturbance. As shown in Map 2, locations were selected within each quadrant and some were located in the buffer area around the site.

- One area was sampled because of its proximity to a waste area (paint shack) (Photo 5). It was expected that this area might have different results than the samples in undisturbed locations.

- Location NE03 was selected because it was the least disturbed area on-site and the actual location where the reactor will be built.

- Co-located samples were collected at location NW02 for analysis for quality control and quality assurance purposes.

- Water, soil and vegetation samples were collected at water pumping station (located nearby but off the CNESTEN site).

- For comparison purposes, additional soil, short-lived and long-lived vegetation composite samples were created. These were identified as Upwind Composite and Downwind Composite. The Upwind Composite samples were created from a sample aliquot from the upwind locations NW01, NW03, NE02, and SW03. The Downwind Composite samples were created from a sample aliquot from the downwind locations SW01, SE02, SE03, and NE01. Rational behind these composite samples was to determine a general site background level, not specifically the concentration at one location.

\section{Soil Sampling Protocol}

Sampling followed the procedures in References 1 and 2. In an attempt to find soils in a "natural" state, soil samples were collected in areas where there was little or no visible ground disturbance. Samples from these areas are believed to represent natural background levels and were not expected to have contaminants as the result of ground movement or construction activities.

Surface soil samples were collected from the top $5 \mathrm{~cm}$ of soil using a clean sampling coring device (Photo 1). A total mass of at least 200 grams was collected from each location. The soil surfaces were cleared of any vegetation prior to collection. All sampling personnel coming in contact with the soil wore clean sampling gloves that were replaced after each sample was collected. 
Each surface soil core was placed in a plastic bag, and then doubled bagged. Each bag was labeled with the sampler's initials, date of collection, and the sample location using a permanent marker. All tools used in soil sampling were cleaned after each location using deionized water and then dried with disposable towels. Gloves were discarded after each location.

\section{Short-lived Vegetation Sampling Protocol}

For comparison purposes, short-lived vegetation was collected as near as possible to the soil sampling locations. Short-lived vegetation samples consisted primarily of miscellaneous dry native annual grasses composed primarily of the genus Bromus and Poa. These grasses would exhibit contamination from recent activities. Broad-leafed or noticeably different vegetation types were intentionally avoided (Photo 2). Grasses were cut using clean scissors and the scissors were cleaned after each sample was collected. The dried grasses were placed in lunch bag size paper sacks that were securely closed with tape. Three bags of native short-lived vegetation were collected at each location. Each sample was labeled with the location identifier, sampler's initials, date, and requested analysis.

\section{Long-lived Vegetation Sampling Protocol}

Cork oak (Quercus suber) was chosen for sampling because it is an important agricultural resource in this region. Results from cork oak bark represent long-term background activity.

One lunch bag sized (32 oz) paper bag of cork was collected from the outer bark of the tree closest to the soil sampling location. The specific tree location was documented in the field notebook. Samples were obtained by chipping off the top layer of cork using a knife or pick-hammer (Photo 3). Using this procedure, it was impossible to limit the depth of each cork segment, therefore more mass was collected than was analyzed.

Because the cork oak samples came off the trees at varying depths and dimensions, portions of the cork at each location were weighed and homogenized using a scale and a laboratory blender. The larger cork pieces were pulverized into finer non-uniform particles approximately $2-4 \mathrm{~mm}$ in diameter. This was done using a dedicated (newly purchased) industrial blender. The blender was thoroughly cleaned using de-ionized water after each composite.

Once pulverized, approximately 50 grams from each of the upwind and downwind locations was composited to create the composite samples for long-lived vegetation. Approximately 200 grams of pulverized cork for each composite was supplied to the laboratory for all the analysis. 


\section{Water Sampling Protocol and Locations}

Water sampling included sampling of two groundwater wells and one surface water location (Map 1). The well closest to the Site was the "Pumping Station" well, located approximately $2 \mathrm{~km}$ to the west (ID number S-ENSO9ZO-0W on analytical Tables 7, 8, and 9). The second groundwater sampling was located approximately $6 \mathrm{~km}$ northwest of the Site, at well ENSO6Z5 (Map 1) and identified as S-ENSO6Z5 on Tables 7, 8, and 9. The pumping station well provides water to the CNESTEN site based on hydrogeological data provided by CNESTEN (Charafat Afailal, January 2002, Section 2.9. Hydrogeologie, excerpt from unknown French report), both wells are located generally down gradient from the site.

Hydrogeological data provided by CNESTEN suggests the regional water supply in this area is pumped from a confined aquifer. The confined aquifer is separated from the phreatic or upper unconfined aquifer by a clay-marl layer that extends north and westward over much of the Maamora Forest, and specifically in the area of the Site sample locations. Data suggests that this clay-marl layer terminates northwest of the ENSO6Z5 well and is not present near the Sebou River where the Discharge Point is located (Map 1). The regional aquifer is composed of Mio-Pliocene aged sands and gravels that crop out to the south and east where the aquifer is recharged, and thickens toward the north and west. Flow gradients from the Site are $0.5-0.8 \mathrm{~cm} / 100 \mathrm{~cm}$ flowing northward toward Kenitra and northwestward toward the Mehdiya area near well location ENSO6Z5.

At both groundwater sampling locations, samples were obtained after the wells pumped approximately 3 well volumes of water. Information such as $\mathrm{pH}$ and temperature were recorded for both wells and for the water at the discharge point and is shown in Table 1. No water depth information was provided at the Pumping Station well because the well was under pressure and surface facilities would not allow for a water depth measurement. At Well ENSO6Z5 a depth of $51.4 \mathrm{ft}$. was measured. At both wells, the screen depths/aquifer depths are not known but it is assumed that both wells were producing from the confined aquifer. Detailed information on well construction may be obtained from the Morocco Ministry of Environment.

Sampling protocol for water was done by triple rinsing polyethylene bottles and then filling, labeling, taping container lids, bagging in plastic zip-lock bags, and labeling the bags with the sample information. During all sampling and packaging, rubber gloves were worn. There were no preservation or special handling measures taken for water samples due to field limitations.

Surface water sampling at the Discharge Point (Map 1, Photo 4) included relatively moderate sampling methods using a polyethylene bucket and rope mechanism. This sample was taken to establish a baseline water analysis at the river at the "Future" CNESTEN Discharge Point. Approximately $500 \mathrm{ml}$ of water was drafted from the river and poured into $100 \mathrm{ml}$ polyethylene bottles. Standard labeling and handling protocols as mentioned above were followed. 


\section{Sample Shipment and Processing}

Due to import controls placed on the importation of soil and vegetation into the United States, LLNL was required to obtain United States Department of Agriculture (USDA) permits before samples could be shipped from Morocco. LLNL was able to use an existing Soil Permit Number S-46701; however, a new application was required for the vegetation samples. There is no control for water samples; these water samples were sent to the US in early September 2002.

The vegetation permit (USDA Permit Number 63011) was granted on July 22, 2002. Computer and communication problems resulted in delay of the sample shipment from Morocco. The remaining soil samples were received by LLNL in early November. All sample inventories were complete and intact upon arrival.

Upon arrival from the Unites States Custom Department, all vegetation and soil samples were frozen by LLNL staff for at least 24 hours to eliminate any potential biological activity. Because of budgetary limitations, some samples were not analyzed and some were included in composites. One set of all three sample media, collected at the primary water pumping station, was also analyzed. All water samples were analyzed.

\section{Analysis}

Analytical processing of future samples will be performed at the CNESTEN Maamora site laboratory; however, at the time of this project, the CNESTEN laboratory was not yet operational. As a result, LLNL assumed responsibility for obtaining the analyses of the samples collected during this project. The CNESTEN Maamora site laboratory will perform future environmental analysis with duplicate analysis being performed by LLNL.

A certified laboratory in the United States performed all of the analyses. An electronic copy of all data is included on a CD along with this report. Printed copies of the data are available on request.

\section{Analytical Methods}

The soil and vegetation samples were analyzed for total threshold limit concentration values: Title 22 (TTLC) metals, pesticides (Environmental Protection Agency [EPA] 8081) and screened for PCBs. These samples were processed in accordance with Code of Federal Regulations, Title 40, "EPA Methods", California Code of Regulations Title 22 "Standard Methods".

The water samples were analyzed for a suite of general mineral constituents, National Pollution Discharge Emission Standard (NPDES) metals, and pesticides using EPA Method 525. The water samples were also screened for PCBs. 


\section{Data Interpretation}

\section{Soil}

The primary concern for contamination in surface soil is the migration of these contaminants to the groundwater. A secondary concern for surface contamination is possibility that the contaminants can be taken up by plants, fed upon by vertebrates and invertebrates, and thus move into the ecosystem. The EPA is in the process of revising ecological soil screening levels (EcoSSLs) that take this into account. The "Draft Ecological Soil Screening Level (Eco-SSL) Guidance and Exhibits, and Related Federal Register Notice" can be found at the following web site:

http://www.epa.gov/superfund/programs/risk/ecorisk/ecossl.htm

Although these EcoSSLs are currently in draft, there is valuable information available for determining site-specific background concentrations. Attachment 1 is a portion of an earlier version of that document showing the generic soil screening levels (SSLs) using conservative assumptions. The SSL values are based on conservative dilutionattenuation factors (DAF). These factors are used to account for natural processes that reduce the contaminant concentration in the subsurface. DAF factors can be as low as 1 or as high as 100 depending on the depth to groundwater and the type of subsurface geology. LLNL did not have access to such subsurface data and therefore can only present possible DAF factors for CNESTEN Lab review. For guidance on determining the appropriate DAF factor for the Moroccan area, see Reference 3 or the web site listed above.

Unfortunately the holding times for the organochlorine pesticides (EPA 8081) and PCBs were exceeded, so nondetections in this data should not be definitively interpreted that no contamination is present. However, PCBs and organochlorines are very stable in the environment and the results of this data are a good indication that these semivolatile and volatile compounds are not present at levels of concern in the soil samples. Several samples detected DDE and DDT, which is not unexpected for agricultural areas where such pesticides are used for mosquito/malaria eradication. The pesticide detections are far below the EPA SSL of 3 and $2 \mathrm{mg} / \mathrm{kg}$ for DDE and DDT respectively using DAF=1. See Table 2 for the pesticides in soil data.

Metals in soil are also very stable and these data can be considered representative of the concentration of the metals at the time of sampling. Only chromium and mercury had their holding times exceeded, these two metals and the volatile organic compounds should be analyzed again when analyses can be perform within the required holding times.

Table 3 lists data for the metals detected in soil. Arsenic, chromium and nickel exceeded the $\mathrm{DAF}=1$ but no metals were detected above the $\mathrm{DAF}=20$. These levels are typical of environmental metals data. 
Location NE3 had the only detection for mercury. While the concentration was very low $(0.01 \mathrm{mg} / \mathrm{kg})$ the origin of this is unknown; therefore, it warrants further investigation.

\section{Vegetation}

Two of the inorganic analytes, barium and potassium, were detected in every soil and every short-lived vegetation sample. Chart 1 presents the metals detected in soils and vegetation samples, Table 4 presents the pesticides detected in short- and long-lived vegetation and Table 5 presents the metals detected in the vegetation samples.

Potassium is naturally present in soils world-wide so this result was expected and is consistent with environmental data from LLNL and elsewhere. Potassium is also an essential plant macronutrient (Reference 4) and thus will be found in large quantities in all plants. It is highly mobile and used by plants (and by animals as well) for osmoregulation. Some inorganic constituents will bio-concentrate in vegetation through intake from air, water or, soil. This was seen here, as concentrations were higher in vegetation than soil for some metals.

In addition to the co-located metals discussed above from Chart 1 , arsenic, chromium, and vanadium were detected in all six of the soil samples (Table 6). Arsenic was detected in two of the vegetation samples; chromium and vanadium were not detected in any of the vegetation samples. None of these substances are essential plant nutrients, but could accumulate in plant tissue if found in the soil in high enough concentrations.

In contrast, there were fewer detections of copper, lead, and zinc in the soil samples than in the short-lived vegetation samples. One metal, mercury, was detected in one soil sample, but none of the vegetation samples. Copper and zinc are essential plant micronutrients. Uptake of these micronutrients by plants will occur at even low soil concentrations (i.e., below the detection limit). Copper is essential in cellular redox reactions. Copper deficiency is usually noted in the range of 3 to $5 \mathrm{mg} / \mathrm{kg}$ or below in leaf tissue. Copper can be toxic at higher concentrations, above 20 to $30 \mathrm{mg} / \mathrm{kg}$. Zinc is important to enzyme function. Zinc deficiency in plants is common due to poor soil nutrition and interactions with phosphorus. Critical deficiency levels are below about 15 to $20 \mathrm{mg} / \mathrm{kg}$ zinc per dry wt of leaves. If zinc concentrations are very high in soil, zinc toxicity can result. Critical toxicity levels are above about 400 to $500 \mathrm{mg} / \mathrm{kg}$ dry wt. Copper and zinc concentrations found in the vegetation samples were on the lower end of normal range. Lead is not an essential nutrient, but depending on its form, can be very mobile and taken up readily by plants. Airborne lead can be taken up by plants through stomata.

No limits or standards for vegetation have been established by the Moroccan Ministry of the Environment. However, sampling and monitoring vegetation can provide information on the presence and movement of such contaminants.

\section{Water}

Analytical results for both groundwater sample locations and for the Discharge Point are shown on Tables 7, 8, and 9. Results on Tables 7 and 8 are for metals and general 
minerals and are both compared to the Morocco Ministry of Environment, "Terms de Reference". The comparison is based on the Ministry of Environment Value Limits for Direct Discharge, and values (where provided) are shown on Tables 7 and 8 . However, it must be pointed out that many of the constituents analyzed are not shown on the Ministry of Environment tables so there is no basis of comparison. Analytical results (Table 9) for semivolatile compounds (semivolatiles, organochlorine pesticides, nitrogen or phosphorous pesticides) are analyzed following U.S. EPA Method 525.2 and compared to primary USEPA drinking water standards.

The interpretation of these data are important to set a baseline chemical analysis for the Maamora Site. The interpretation of NPDES metals analyses (Table 7) indicates that no metals values exceeded the Ministry of Environment values for direct discharge water values. For general minerals (Table 8), some elevated values are shown at the Discharge Point. These elevated values should be expected due to high sediment influx and current runoff from metropolitan, industrial and commerce areas located upstream for the sample location. Table 9 presents a list of volatile organic compounds for which USEPA maximum contaminant values are available. The comparison of analytical results and MCL values indicates that no elevated levels were present based on MCL comparison. Other compounds were analyzed as part of the EPA Method 525.2 but were not included in Table 9 because USEPA MCL values were not available for comparison. For a complete list of all analyses, see the Excel spreadsheet titled "analysis.xls" included with this report.

The holding time for water analyses using EPA Method 525.2 was exceeded because of CNESTEN limitations on analytical laboratory capabilities as well as shipping and export problems. However, even though the water samples were analyzed beyond their holding times, many of the normal physical values such as $\mathrm{pH}$, conductivity, TDS, and general minerals/metals data did show expected values throughout the data set and suggest that much of the data can be interpreted to be representative of site conditions. This was especially true in the Discharge Point data set.

Based on the interpreted confined aquifer conditions of the CNESTEN Site and also of Well ENSO6Z5, it is not surprising that there were no overall elevated values of contaminants in these wells. Based on the interpreted confined aquifer conditions at the sampling sites, it appears that if any surface contaminants were present at the site, they could not have affected the groundwater at the sample locations. However, it must be emphasized that additional hydraulic information regarding well screen depths, well pressure data, pumping history, well boring logs data, and regional hydrogeologic data should be used in conjunction with this report to accurately understand the hydraulic conditions at the groundwater sample locations

\section{Recommendations}

Because of limitations in shipping equipment from the United States to Morocco and analytical holding times, some important environmental sampling and analyses were not performed. This sampling includes air monitoring for metals and sampling for 
volatile organic constituents in water, vegetation, and soils. These analyses are important and are necessary to fully characterize the background levels at the site. LLNL recommends that CNESTEN staff perform this sampling and analysis before the start of the reactor and preferably before construction activity begins. Guidance and further training can be supplied by LLNL if requested.

We recommend quarterly sampling of all matrices (water, soil, and short-lived vegetation). Frequent monitoring of environmental media provides good baseline data for evaluation of future measurements, as well as providing an early indicator should a problem arise.

Though sediment sampling in the Mehdia/Oued Sebou River was not part of the scope of this project, it is recommended that sediments and more water samples be collected at this discharge point. Sediments show the accumulation of contaminants where surface waters may not. In addition, sampling water at different depths, time of day, and seasons will produce different contaminant levels. LLNL supports sampling and analyzing water to ensure effluent limits are met before discharging to the river.

We recommend re-sampling both groundwater well locations as well as the Discharge Point. This recommendation has two goals: provide a new set of samples to analyze within proper holding times, and secondly, provide time to collect additional information regarding site and regional hydraulic conditions that may lead to alternate groundwater sampling locations, different sampling techniques, or provide additional physical groundwater hydrology data that can be used to establish risk-based environmental practices for future land use at CNESTEN. Additional hydrogeological data may be useful to identify any unconfined aquifers or perched aquifers that may be used for future drinking water supplies. These aquifers would be more vulnerable to any future surface environmental discharge.

\section{Acknowledgements}

This work was accomplished through a team-effort between Lawrence Livermore National Laboratory and The Moroccan National Center for Nuclear Energy Sciences and Techniques (CNESTEN). The LLNL staff participating in Morocco included Rick Blake, Dr. Bryan Bandong, and Paris Althouse. Additional thanks to LLNL support from Don MacQueen, Dr. Tina Carlsen and Gretchen Gallegos. The CNESTEN participants include Ms Itimad Soufi, Smail Al-Hilali, Charafat Afailal, and sampling team members: Hatim Belghit and Nabil Dehbi (Photo 6).

A very special acknowledgement of Mr. Boujemaa Zenzouni, Department Head for Technical Cooperation and Training, for coordinating this effort.

Additional thanks to Mo Bissani, Sister Laboratory Program Manager, and Maggie Manning, NNSA Program Manager, for supporting and funding this project. 


\section{References}

1. American Society for Testing and Materials, Standard Practices for Sampling Surface Soil for Radionuclides, American Society for Testing and Materials, Philadelphia, PA (C998-90), 1990

2. US DOE/EH-0173T, Environmental Regulatory Guide for Radiological Effluent Monitoring and Environmental Surveillance, US DOE, Assistant Secretary for Environment, Washington D.C. 20585, 1991

3. EPA 540/R95/128, Soil Screening Guidance: Technical Background Document, May 1996

4. Marschner, H. 1993. Mineral Nutrition of Higher Plants. Academic Press Inc. San Diego 
Map 1. CNESTEN Site and sampling locations

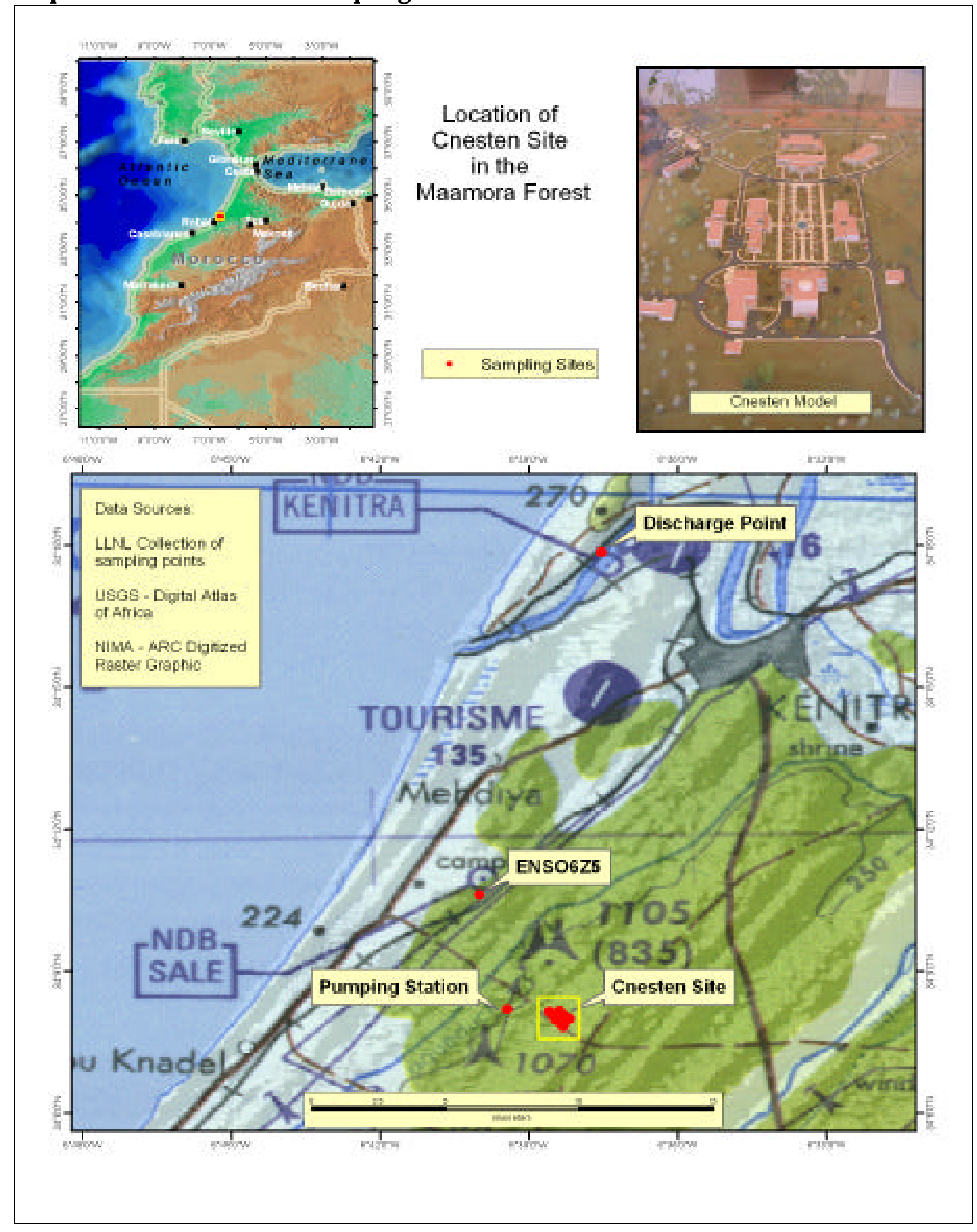




\section{On site CNESTEN Sampling locations}

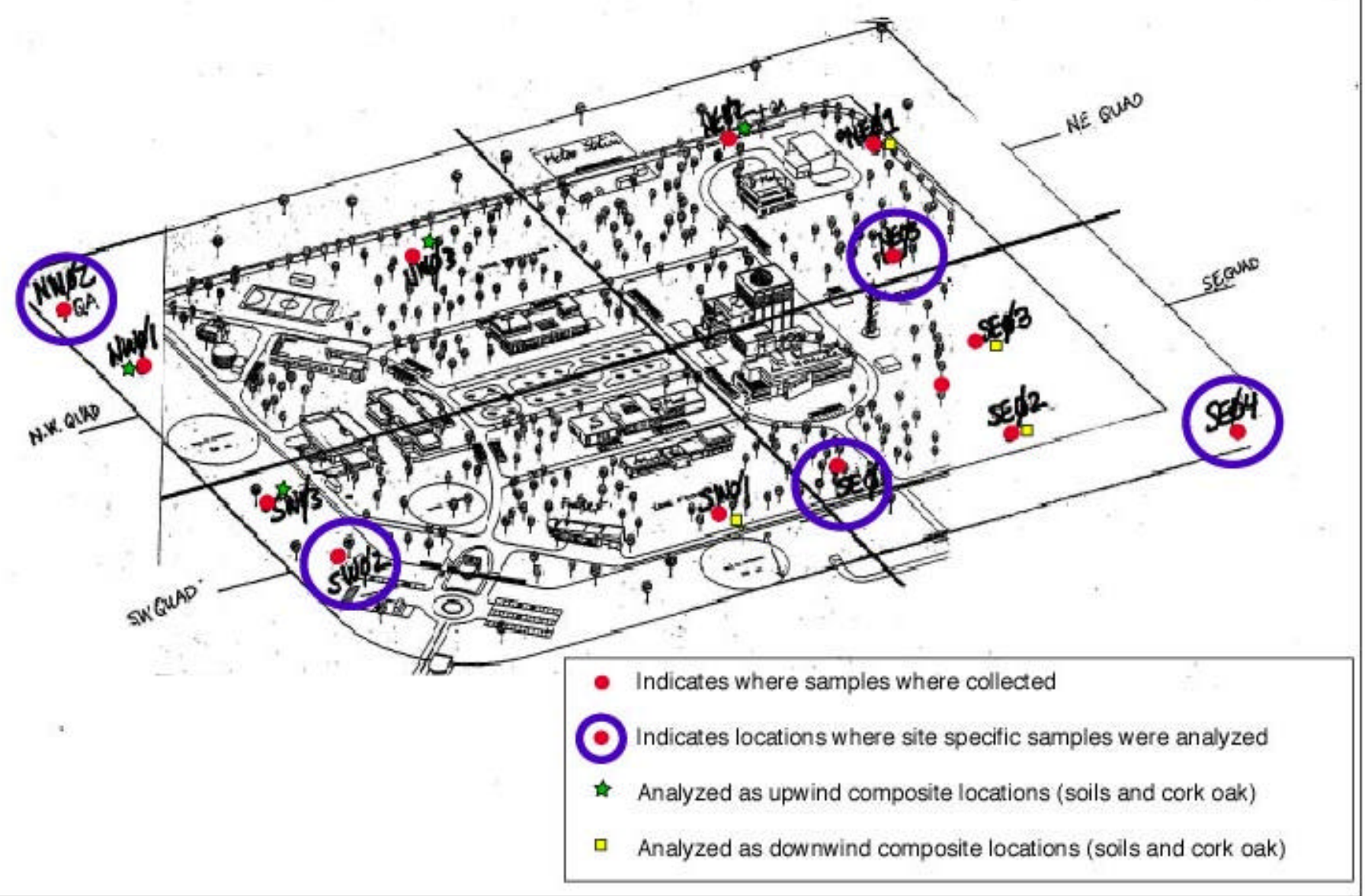




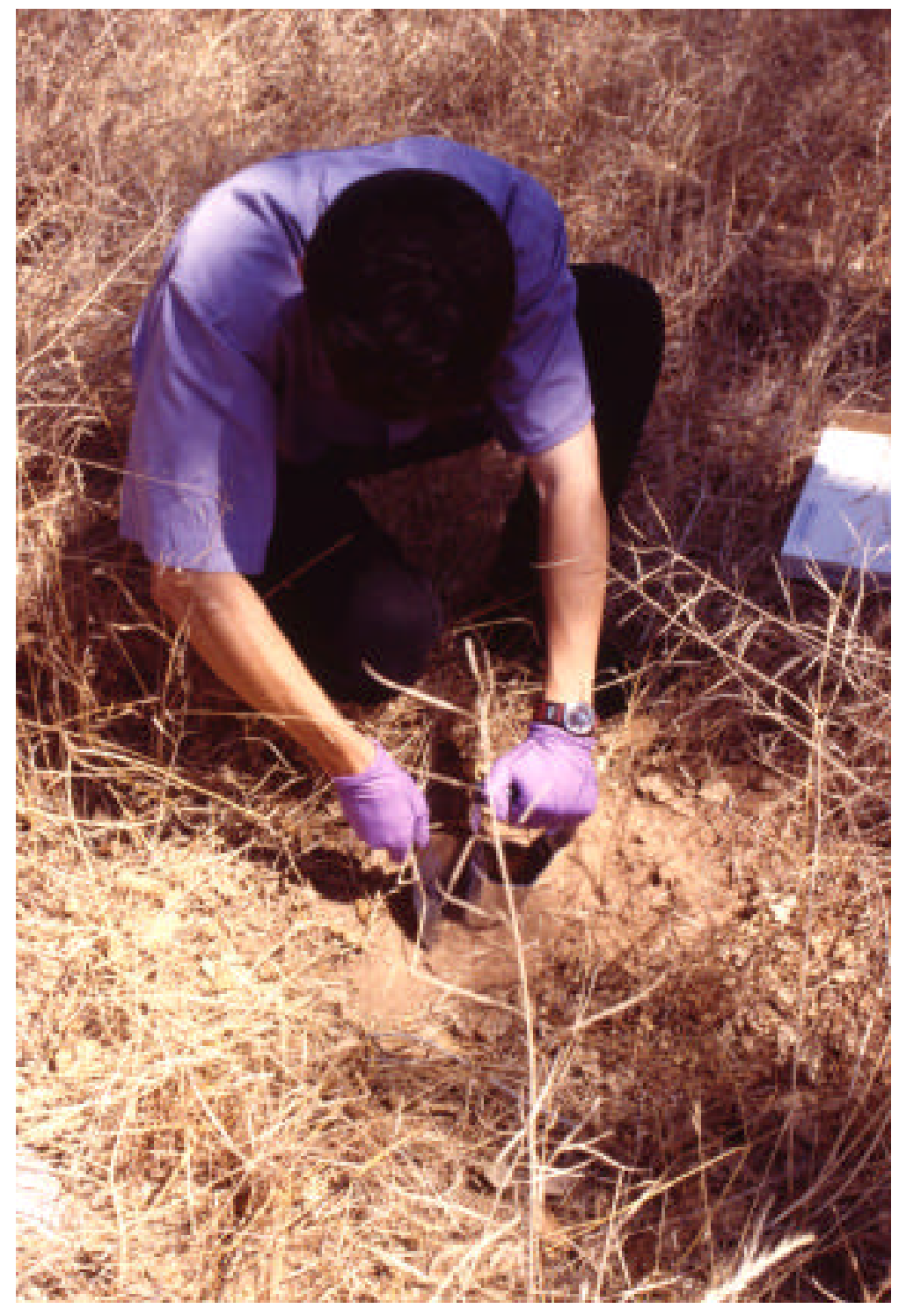

Photo 1. Soil sampling 


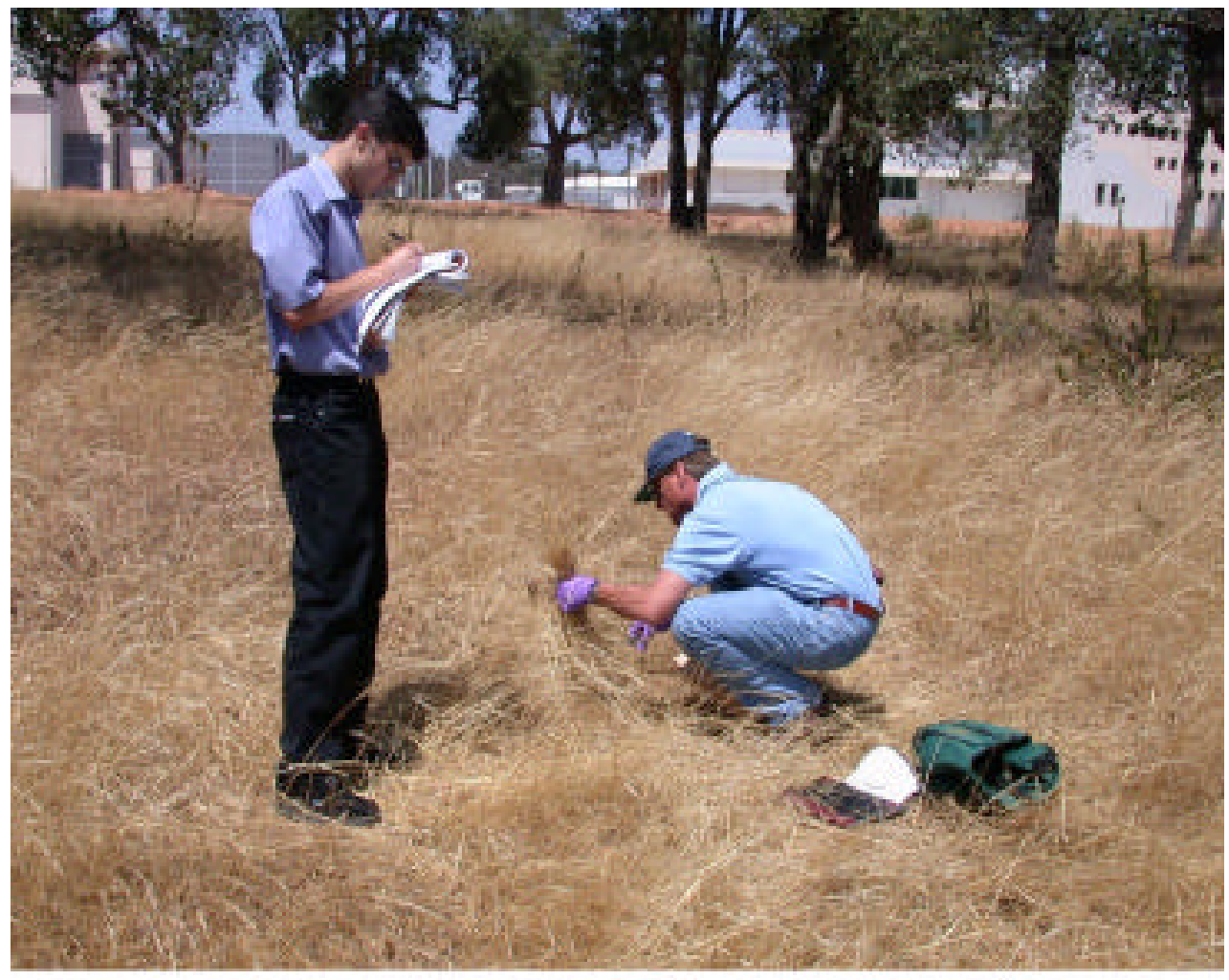

Photo 2. Sample documentation and collection of short-lived vegetation 


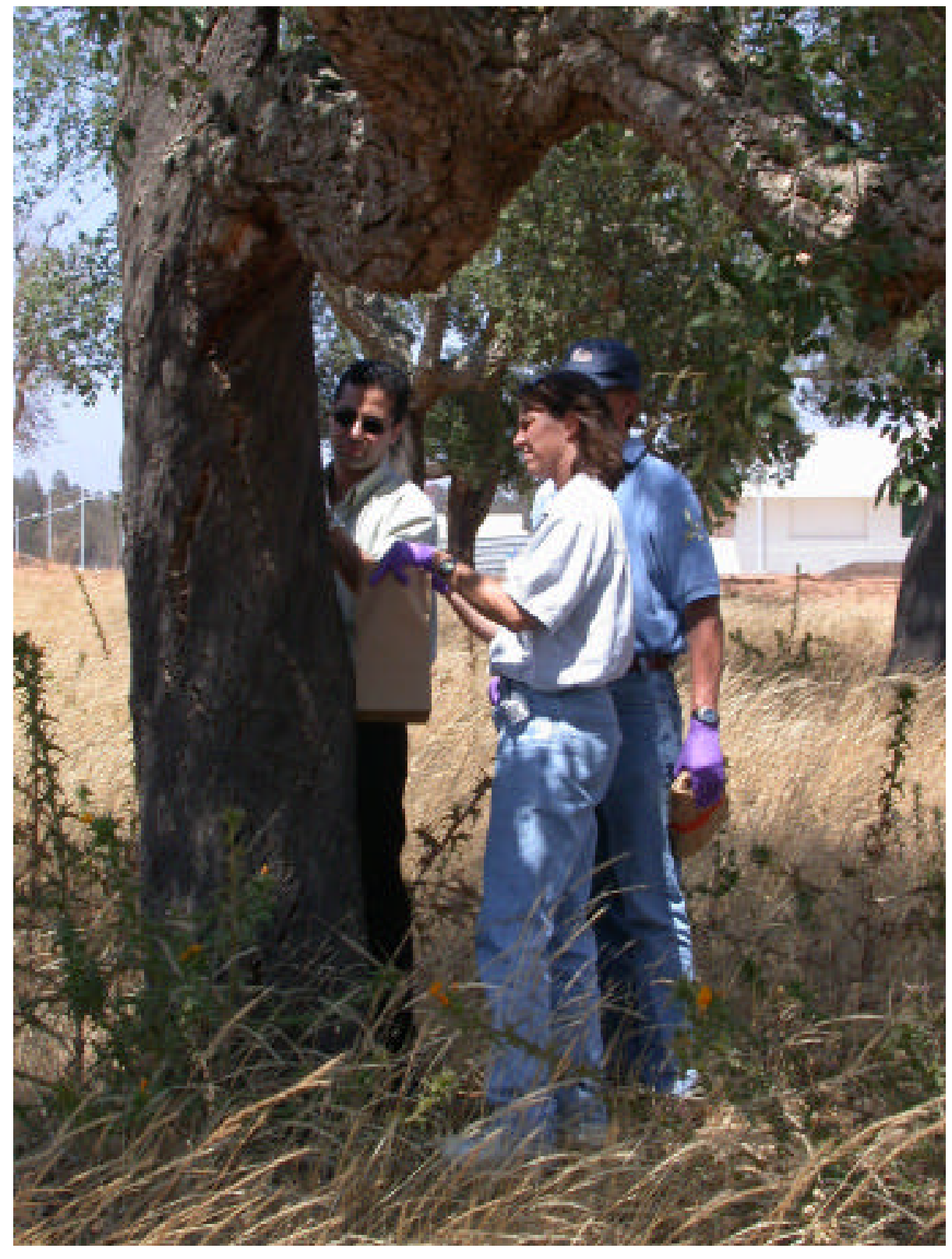

Photo 3. Long-lived vegetation (cork oak) collection 


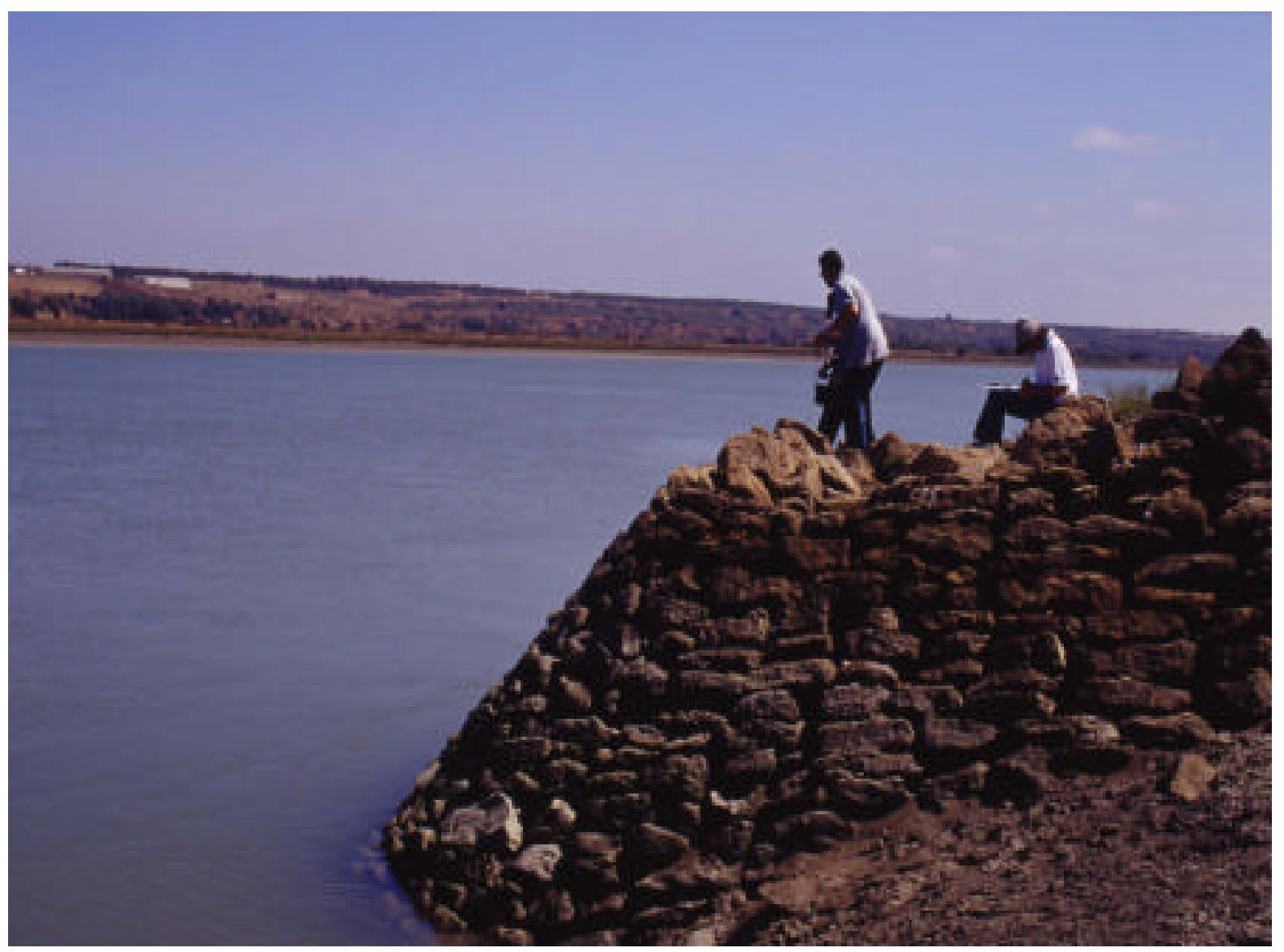

Photo 4. Water Discharge location 


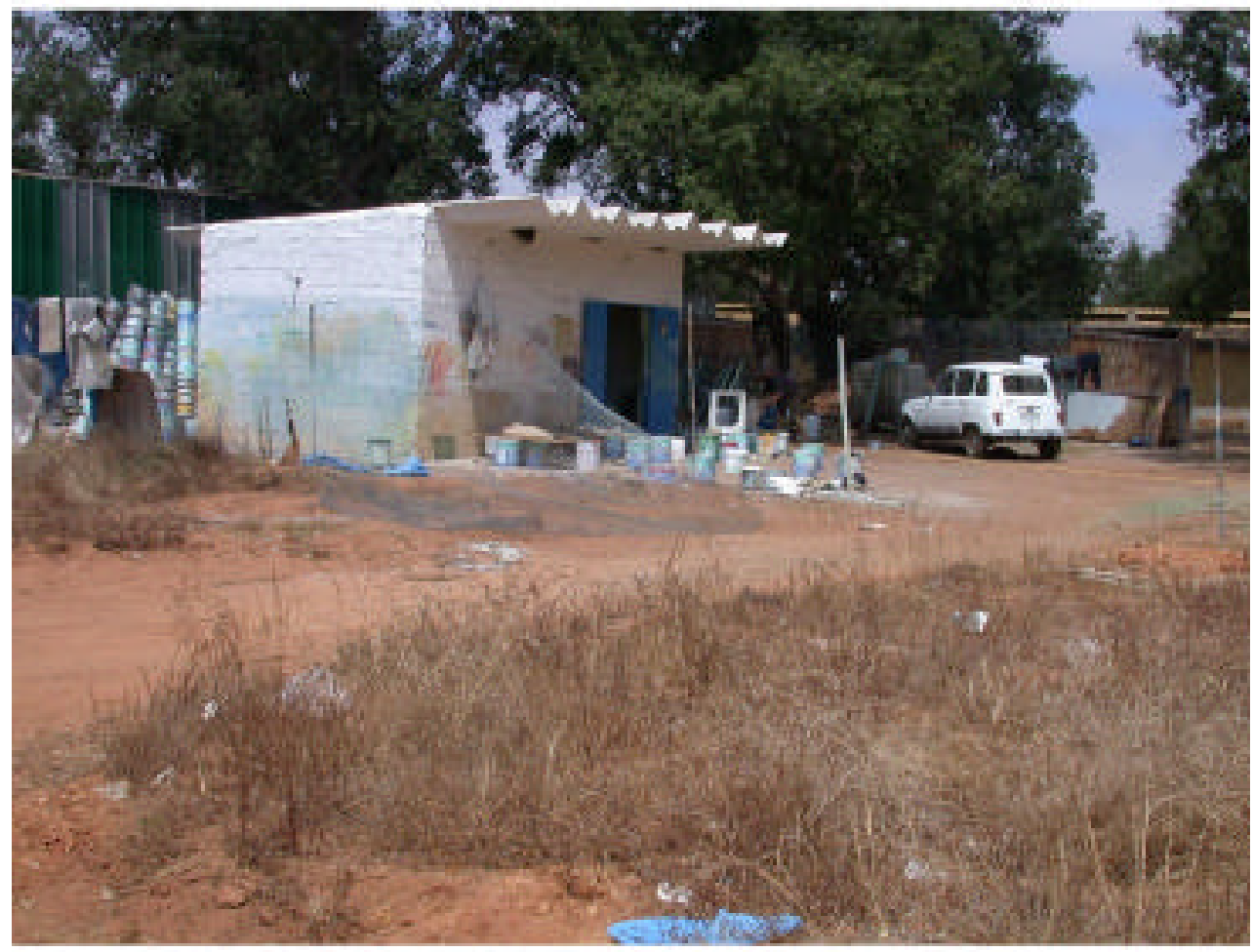

Photo 5. Location SE04, paint shack

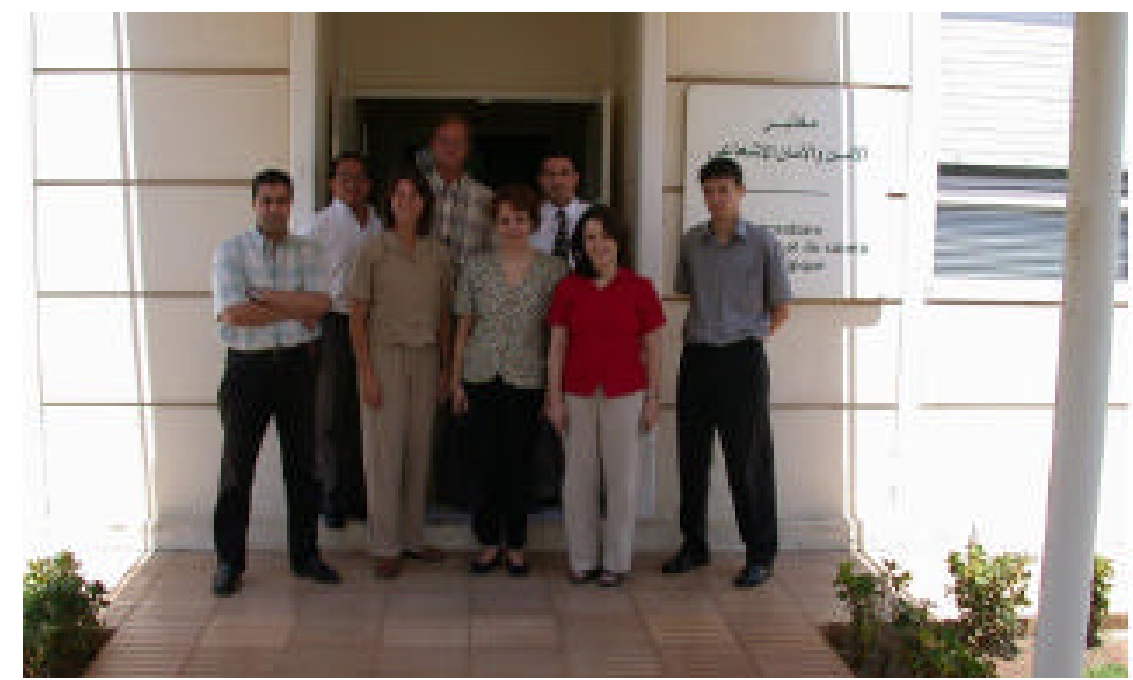

Photo 6. Sampling Team with Ms. Soufi, Mr. Al Hilali and Charafat Afailal 


\section{Table 1. Sampling locations and field notebook data}

\begin{tabular}{|c|c|c|c|c|c|c|c|c|}
\hline Location Id & $\begin{array}{l}\text { Date } \\
\text { collected }\end{array}$ & $\begin{array}{l}\text { \# of } \\
\text { containers }\end{array}$ & s collected & Requested Analysis & Latitude(DD) & $\begin{array}{l}\text { Longitude } \\
\text { (DD) }\end{array}$ & $\begin{array}{l}\text { Altitude } \\
(\mathbf{H A E})\end{array}$ & Comments \\
\hline NW-01-SO & 3-Jul-02 & & 1 soil & $\begin{array}{l}\text { Resuicides/PCBs, Nutrients, Metals } \\
\text { Pestids }\end{array}$ & $\mathrm{N} 34.135753$ & W6.64304 & & 3 soils collected in buffer zone \\
\hline NW-01-VG & 3-Jul-02 & & 3 short-lived veg & Pesticides/PCBs, Nutrients, Metals & & & & dry annual grasses, \\
\hline NW-01-VG & 3-Jul-02 & & 1 long-lived veg & Pesticides/PCBs, Nutrients, Metals & & & & cork collected 6 meters north of GPS'ed point \\
\hline $\mathrm{NW}-02-\mathrm{SO}$ & 3-Jul-02 & & 1 soil & Pesticides/PCBs, Nutrients, Metals & N34.135865 & W6.639777 & 143531 & Northern most corner of site, soils slightly disturbed but not from vehicle traffic. \\
\hline NW-02-VG & 3-Jul-02 & & 3 short-lived veg & Pesticides/PCBs, Nutrients, Metals & & & & 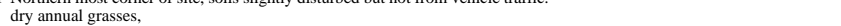 \\
\hline NW-02-VG & 3-Jul-02 & & 1 long-lived veg & Pesticides/PCBs, Nutrients, Metals & & & & only cork in the vicinity, 2 meters NE of GPS point. \\
\hline NW-03-SO & 3-Jul-02 & & 1 soil & Pesticides/PCBs, Nutrients, Metals & $\mathrm{N} 34.134751$ & W6.638610 & 139.014 & 4 undisturbed soils \\
\hline NW-03-VG & 3-Jul-02 & & 3 short-lived veg & Pesticides/PCBs, Nutrients, Metals & & & & dry annual grasses, \\
\hline NW-03-VG & 3-Jul-02 & 0 & long-lived veg & no cork oak available & & & & no cork oak trees \\
\hline NW-QA-SO & 3-Jul-02 & & 1 soil & Pesticides/PCBs, Nutrients, Metals & N34.135865 & W6.639777 & 143.531 & Northern most corner of site, soils slightly disturbed but not from vehicle traffic. \\
\hline NW-QA-VG & 3-Jul-02 & & 3 short-lived veg & Pesticides/PCBs, Nutrients, Metals & & & & dry annual grasses, \\
\hline NW-QA-VG & 3-Jul-02 & & 1 long-lived veg & Pesticides/PCBs, Nutrients, Metals & & & & only cork in the vicinity, 2 meters NE of GPS point. \\
\hline NE-01-SO & 3-Jul-02 & & 1 soil & Pesticides/PCBs, Nutrients, Metals & N34.133148 & W6.636248 & 145.197 & 7 soil collected west of haz waste facity \\
\hline NE-01-VG & 3-Jul-02 & & 3 short-lived veg & Pesticides/PCBs, Nutrients, Metals & & & & 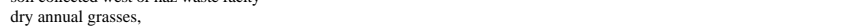 \\
\hline NE-01-VG & 3-Jul-02 & & 1 long-lived veg & Pesticides/PCBs, Nutrients, Metals & & & & 15 meters south of GPS position \\
\hline NE-02-SO & 3-Jul-02 & & 1 soil & Pesticides/PCBs, Nutrients, Metals & N34.133907 & W6.63750 & 129.243 & 3 undisturbed soils near met tower \\
\hline NE-02-VG & 3-Jul-02 & & 3 short-lived veg & $\begin{array}{l}\text { Pesticides/PCBs, Nutrients, Metals } \\
\text { PCs }\end{array}$ & N34.15390t & ט & 129.243 & 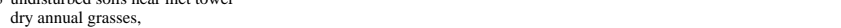 \\
\hline NE-02-VG & 3-Jul-02 & 0 & long-lived veg & $\begin{array}{l}\text { no cork oak available } \\
\text { nolnt, Nitals }\end{array}$ & & & & no cork oak trees \\
\hline NE-03-SO & 3-Jul-02 & & 1 soil & Pesticides/PCBs, Nutrients, Metals & $\mathrm{N} 34.132404$ & W6.63787 & 142.295 & 5 undisturbed soils \\
\hline NE-03-VG & 3-Jul-02 & & 3 short-lived veg & Pesticides/PCBs, Nutrients, Metals & & & & dry annual grasses, \\
\hline NE-03-VG & 3-Jul-02 & & 1 long-lived veg & Pesticides/PCBs, Nutrients, Metals & & & & cork oak 10 meters south of GPS point \\
\hline SW-01-SO & 3-Jul-02 & & 1 soil & Pesticides/PCBs, Nutrients, Metals & N34.132865 & W6.60999 & 130.199 & soils may have been distrurbed- movement 15 meters to the north and east \\
\hline SW-01-VG & 3-Jul-02 & & 3 short-lived veg & Pesticides/PCBs, Nutrients, Metals & & & & dry annual grasses, \\
\hline SW-01-VG & 3-Jul-02 & & 1 long-lived veg & $\begin{array}{l}\text { Pesticides/PCBs, Nutrients, Metals } \\
\text { PCBs }\end{array}$ & & & & 5-7 meters west from GPS point \\
\hline SW-02-SO & 3-Jul-02 & & 1 soil & Pesticides/PCBs, Nutrients, Metals & N34.134122 & W6.641796 & 134.593 & 3 soil collected in buffer zone, no undistrubed soil avaiable inside perimeter \\
\hline SW-02-VG & 3-Jul-02 & & 3 short-lived veg & Pesticides/PCBs, Nutrients, Metals & & & & $\begin{array}{l}\text { dry annual grasses, } \\
\text { Solic, }\end{array}$ \\
\hline SW-02-VG & 3-Jul-02 & & 1 long-lived veg & Pesticides/PCBs, Nutrients, Metals & & & & cork oak 6 meters to west of GPS point \\
\hline SW-03-SO & 3-Jul-02 & & 1 soil & Pesticides/PCBs, Nutrients, Metals & $\mathrm{N} 34.134664$ & W6.641579 & 133.285 & 5 soil collected in buffer zone \\
\hline SW-03-VG & 3-Jul-02 & & 3 short-lived veg & Pesticides/PCBs, Nutrients, Metals & & & & dry annual grasses, \\
\hline SW-03-VG & 3-Jul-02 & & 1 long-lived veg & Pesticides/PCBs, Nutrients, Metals & & & & cork oak 10 meters west of GPS \\
\hline SE-01-SO & 2-Jul-02 & & 1 soil & Pesticides/PCBs, Nutrients, Metals & N34.133262 & W6.640234 & 138.621 & I soil collected in undisturbed cork oak grove \\
\hline SE-01-VG & 2-Jul-02 & & 3 short-lived veg & Pesticides/PCBs, Nutrients, Metals & & & & dry annual grasses, \\
\hline SE-01-VG & 2-Jul-02 & & 1 long-lived veg & Pesticides/PCBs, Nutrients, Metals & & & & cork oak 10-15 meters NE of GPS position. \\
\hline SE-02-SO & 2-Jul-02 & & 1 soil & Pesticides/PCBs, Nutrients, Metals & N34.131500 & W6.639160 & 141.305 & 5 undisturbed soils \\
\hline SE-02-VG & 2-Jul-02 & & 3 short-lived veg & Pesticides/PCBs, Nutrients, Metals & & & & dry annual grasses, \\
\hline SE-02-VG & 2-Jul-02 & & 1 long-lived veg & Pesticides/PCBs, Nutrients, Metals & & & & cork oak 6 meters north of GPS position \\
\hline SE-03-SO & 2-Jul-02 & & 1 soil & Pesticides/PCBs, Nutrients, Metals & N34.131792 & W6.638027 & 132.77 & 7 undisturbed soils near reactor site \\
\hline SE-03-VG & 2-Jul-02 & & 3 short-lived veg & Pesticides/PCBs, Nutrients, Metals & & & & dry annual grasses, \\
\hline SE-03-VG & 2-Jul-02 & & 1 long-lived veg & Pesticides/PCBs, Nutrients, Metals & & & & not the true closest cork oak, ANTS!, collected sample from tree $30-35$ meters SW of GPS point \\
\hline SE-QA-SO & 2-Jul-02 & & 1 soil & Pesticides/PCBs, Nutrients, Metals & $\mathrm{N} 34.131792$ & W6.638027 & 132.77 & 7 undisturbed soils near reactor site \\
\hline SE-QA-VG & 2-Jul-02 & & 3 short-lived veg & Pesticides/PCBs, Nutrients, Metals & & & & dry annual grasses, \\
\hline SE-QA-VG & 2-Jul-02 & & 1 long-lived veg & Pesticides/PCBs, Nutrients, Metals & & & & not the true closest cork oak, ANTS!, collected sample from tree 30-35 meters SW of GPS point \\
\hline EXTRA SAMPLES & & & & & & & & \\
\hline $\begin{array}{l}\text { SE-04-SO } \\
\text { SE-04-VG }\end{array}$ & $\begin{array}{l}\text { 4-Jul-02 } \\
\text { 4-Jul-02 }\end{array}$ & & $\begin{array}{l}1 \text { soil } \\
3 \text { short-lived veg }\end{array}$ & $\begin{array}{l}\text { Pesticides/PCBs, Nutrients, Metals } \\
\text { Pesticides/PCBs, Nutrients, Metals }\end{array}$ & N34.130230 & W6.638549 & 144.574 & $\begin{array}{l}4 \text { buffer zone undisturbed soil, however this loaction upgradiantfrom a staging area for oil drmus, paint cans, misc. haz waste. } \\
\text { dry annual grasses, }\end{array}$ \\
\hline SE-04-VG & 4-Jul-02 & & 1 long-lived veg & Pesticides/PCBs, Nutrients, Metals & & & & cork oak 6 meters NE of GPS position \\
\hline ENS09Z0-SO & 4-Jul-02 & & 1 soil & Pesticides/PCBs, Nutrients, Metals & $\mathrm{N} 34.136559$ & W6.656990 & 110.755 & 5 soils collected just west of wellhead. \\
\hline ENS09Z0-VG & 4-Jul-02 & & 3 short-lived veg & Pesticides/PCBs, Nutrients, Metals & & & & dry annual grasses, \\
\hline ENS09Z0-VG & 4-Jul-02 & & 1 long-lived veg & Pesticides/PCBs, Nutrients, Metals & & & & corl oak 12 meters west of GPS position \\
\hline ENS09Z0-WA & 4-Jul-02 & & 3 water & $\begin{array}{l}\text { Nutrients, Metals, GENMIN } \\
\mathrm{pH}=7.22 \\
\text { water temp }=25.5^{\circ} \mathrm{C}\end{array}$ & N34.136473 & W6.657187 & 99.991 & $\begin{array}{l}\text { CNESTEN Site water source. Ground water untreated, pumps at } 15-20 \mathrm{~L} / \mathrm{sec} \text {. } \\
\text { Well located Approx } 1 \text { mile offsite southside on main road. }\end{array}$ \\
\hline QA- WA & 4-Jul-02 & & 3 water & $\begin{array}{l}\text { water temp }=25.5 \\
\text { Nutrients, Metals, GENMIN } \\
\mathrm{pH}=7.22 \\
\text { water temp }=25.5^{\circ} \mathrm{C}\end{array}$ & N34.136473 & W6.657187 & 99.991 & $\begin{array}{l}\text { CNESTEN Site water source. Ground water untreated, pumps at 15-20L/sec. } \\
\text { Well located Approx } 1 \text { mile offsite southside on main road. }\end{array}$ \\
\hline ENS06Z5-WA & 4-Jul-02 & & 3 water & $\begin{array}{l}\text { Nutrients, Metals, GENMIN } \\
\mathrm{pH}=6.97 \\
\text { water temp }=21.7^{\circ} \mathrm{C} \\
\text { depth to }\end{array}$ & N34.176959 & W6.666622 & 75.82 & $\begin{array}{l}2 \text { Ground water well- open air, on SidiTaibi near tran station off main road. } \\
\text { Pumped the well for about } 30 \text { seconds sampled from a port in piping }\end{array}$ \\
\hline DischargePT-WA & 4-Jul-02 & & 3 water & $\begin{array}{l}\text { depth to water } 51.4 \mathrm{ft} \\
\text { Nutrients, Metals, GENMIN } \\
\mathrm{pH}=7.76 \\
\text { water temp }=24.8^{\circ} \mathrm{C}\end{array}$ & $\mathrm{N} 34.297660$ & W6.625501 & 48.638 & Discharge point approx 1 hour from the CNESTEN site \\
\hline
\end{tabular}


Table 2. Pesticides in soil

E8081
S-NE3-SO
S-NW2-SO DUP
S-NW2-SO RTN
S-PUMPSTN-SO
S-SE1-SO
S-SE4-SO
S-SW2-SO
S-DNWIND-SO
S-UPWIND-SO

$\mathbf{m g} / \mathbf{k g}$

$7 / 3 / 02$

$7 / 3 / 02$

$7 / 3 / 02$

$7 / 4 / 02$

$7 / 2 / 02$

$7 / 4 / 02$

$7 / 3 / 02$

$7 / 4 / 02$

$7 / 4 / 02$

S-NE3-SO
S-NW2-SO DUP
S-NW2-SO RTN
S-PUMPSTN-SO
S-SE1-SO
S-SE4-SO
S-SW2-SO
S-DNWIND-SO
S-UPWIND-SO

S-UPWIND-SO

$7 / 3 / 02$

$7 / 3 / 02$
$7 / 3 / 02$
$7 / 4 / 02$
$7 / 2 / 02$
$7 / 4 / 02$
$7 / 3 / 02$
$7 / 4 / 02$
$7 / 4 / 02$

\begin{tabular}{|cc|cc|cc|cc|cc|}
\hline & \multicolumn{2}{|c|}{ Chlordane } & \multicolumn{2}{|c|}{ Dieldrin } & Endosulfan I & Endosulfan II & \multicolumn{2}{c|}{$\begin{array}{c}\text { Endosulfan } \\
\text { sulfate }\end{array}$} \\
\hline LOS & CALC & LOS & CALC & LOS & CALC & LOS & CALC & LOS & CALC \\
\hline$<0.005$ & 0 & $<0.002$ & 0 & $<0.002$ & 0 & $<0.002$ & 0 & $<0.002$ & 0 \\
$<0.005$ & 0 & $<0.002$ & 0 & $<0.002$ & 0 & $<0.002$ & 0 & $<0.002$ & 0 \\
$<0.005$ & 0 & $<0.002$ & 0 & $<0.002$ & 0 & $<0.002$ & 0 & $<0.002$ & 0 \\
$<0.005$ & 0 & $<0.002$ & 0 & $<0.002$ & 0 & $<0.002$ & 0 & $<0.002$ & 0 \\
$<0.005$ & 0 & $<0.002$ & 0 & $<0.002$ & 0 & $<0.002$ & 0 & $<0.002$ & 0 \\
$<0.005$ & 0 & $<0.002$ & 0 & $<0.002$ & 0 & $<0.002$ & 0 & $<0.002$ & 0 \\
$<0.005$ & 0 & $<0.002$ & 0 & $<0.002$ & 0 & $<0.002$ & 0 & $<0.002$ & 0 \\
$<0.005$ & 0 & $<0.002$ & 0 & $<0.002$ & 0 & $<0.002$ & 0 & $<0.002$ & 0 \\
$<0.005$ & 0 & $<0.002$ & 0 & $<0.002$ & 0 & $<0.002$ & 0 & $<0.002$ & 0 \\
\hline
\end{tabular}

\begin{tabular}{|rr|cc|cc|cc|cc|}
\hline & \multicolumn{2}{|c|}{$\begin{array}{c}\text { Endrin } \\
\text { Endrin }\end{array}$} & \multicolumn{2}{c|}{ aldehyde } & Heptachlor & $\begin{array}{c}\text { Heptachlor } \\
\text { epoxide }\end{array}$ & Methoxychlor \\
\hline LOS & CALC & LOS & CALC & LOS & CALC & LOS CALC & LOS & CALC \\
\hline$<0.002$ & 0 & $<0.002$ & 0 & $<0.002$ & 0 & $<0.002$ & 0 & $<0.002$ & 0 \\
$<0.002$ & 0 & $<0.002$ & 0 & $<0.002$ & 0 & $<0.002$ & 0 & $<0.002$ & 0 \\
$<0.002$ & 0 & $<0.002$ & 0 & $<0.002$ & 0 & $<0.002$ & 0 & $<0.002$ & 0 \\
$<0.002$ & 0 & $<0.002$ & 0 & $<0.002$ & 0 & $<0.002$ & 0 & $<0.002$ & 0 \\
$<0.002$ & 0 & $<0.002$ & 0 & $<0.002$ & 0 & $<0.002$ & 0 & $<0.002$ & 0 \\
$<0.002$ & 0 & $<0.002$ & 0 & $<0.002$ & 0 & $<0.002$ & 0 & $<0.002$ & 0 \\
$<0.002$ & 0 & $<0.002$ & 0 & $<0.002$ & 0 & $<0.002$ & 0 & $<0.002$ & 0 \\
$<0.002$ & 0 & $<0.002$ & 0 & $<0.002$ & 0 & $<0.002$ & 0 & $<0.002$ & 0 \\
$<0.002$ & 0 & $<0.002$ & 0 & $<0.002$ & 0 & $<0.002$ & 0 & $<0.002$ & 0 \\
\hline
\end{tabular}


Table 2. Pesticides in soil (continued)

\begin{tabular}{|c|c|c|c|c|c|c|c|c|c|}
\hline & & $p, p-[$ & DDD & $p, p-[$ & DDE & $\mathrm{p}, \mathrm{p}-$ & DDT & Toxa & phene \\
\hline & & LOS & CALC & LOS & CALC & LOS & CALC & LOS & CALC \\
\hline S-NE3-SO & $7 / 3 / 02$ & $<0.002$ & 0 & $<0.002$ & 0 & $<0.002$ & 0 & $<0.02$ & 0 \\
\hline S-NW2-SO DUP & $7 / 3 / 02$ & $<0.002$ & 0 & $<0.002$ & 0 & $<0.002$ & 0 & $<0.02$ & 0 \\
\hline S-NW2-SO RTN & $7 / 3 / 02$ & $<0.002$ & 0 & $<0.002$ & 0 & $<0.002$ & 0 & $<0.02$ & 0 \\
\hline S-PUMPSTN-SO & $7 / 4 / 02$ & $<0.002$ & 0 & 0.002 & 0.004 & $<0.002$ & 0 & $<0.02$ & 0 \\
\hline S-SE1-SO & $7 / 2 / 02$ & $<0.002$ & 0 & 0.002 & 0.002 & $<0.002$ & 0 & $<0.02$ & 0 \\
\hline S-SE4-SO & $7 / 4 / 02$ & $<0.002$ & 0 & $<0.002$ & 0 & $<0.002$ & 0 & $<0.02$ & 0 \\
\hline S-SW2-SO & $7 / 3 / 02$ & $<0.002$ & 0 & $<0.002$ & 0 & 0.002 & 0.002 & $<0.02$ & 0 \\
\hline S-DNWIND-SO & $7 / 4 / 02$ & $<0.002$ & 0 & 0.002 & 0.004 & 0.002 & 0.007 & $\mid<0.02$ & 0 \\
\hline S-UPWIND-SO & $7 / 4 / 02$ & $<0.002$ & 0 & $<0.002$ & 0 & $<0.002$ & 0 & $<0.02$ & 0 \\
\hline
\end{tabular}

All non detects except bolded data

LOS= Limit of sensitivity ( minimum detection limit)

$\mathrm{CALC}=$ calculated positive detection 
Table 3. Metals analysis for soils

\begin{tabular}{|c|c|c|c|c|c|c|c|c|c|c|c|}
\hline \multirow[t]{2}{*}{ TTLCMB+K } & \multirow[t]{2}{*}{$\mathrm{mg} / \mathrm{kg}$} & \multicolumn{2}{|c|}{ Antimony } & \multicolumn{2}{|c|}{ Arsenic } & \multicolumn{2}{|c|}{ Barium } & \multicolumn{2}{|c|}{ Beryllium } & \multicolumn{2}{|c|}{ Cadmium } \\
\hline & & LOS & CALC & LOS & CALC & LOS & CALC & LOS & CALC & LOS & CALC \\
\hline S-NE3-SO & $7 / 3 / 02$ & $<1$ & 0 & 0.5 & 2.2 & 5 & 19 & $<0.5$ & 0 & $<1$ & 0 \\
\hline S-NW2-SO DUP & $7 / 3 / 02$ & 1 & 0 & 0.5 & 1.3 & 5 & 8 & $<0.5$ & 0 & 1 & 0 \\
\hline S-NW2-SO RTN & $7 / 3 / 02$ & 1 & 0 & 0.5 & 1.3 & 5 & 9 & $<0.5$ & 0 & 1 & 0 \\
\hline S-PUMPSTN-SO & $7 / 4 / 02$ & 1 & 0 & 0.5 & 0.8 & 5 & 11 & $<0.5$ & 0 & 1 & 0 \\
\hline S-SE1-SO & $7 / 2 / 02$ & 1 & 0 & 0.5 & 1.3 & 5 & 14 & $<0.5$ & 0 & 1 & 0 \\
\hline S-SE4-SO & $7 / 4 / 02$ & 1 & 0 & 0.5 & 1.1 & 5 & 15 & $<0.5$ & 0 & 1 & 0 \\
\hline S-SW2-SO & $7 / 3 / 02$ & 1 & 0 & 0.5 & 1.5 & 5 & 13 & $<0.5$ & 0 & 1 & 0 \\
\hline S-DNWIND-SO & $7 / 4 / 02$ & 1 & 0 & 0.5 & 1.3 & 5 & 10 & $<0.5$ & 0 & 1 & 0 \\
\hline S-UPWIND-SO & $7 / 4 / 02$ & 1 & 0 & 0.5 & 3.1 & 5 & 11 & $<0.5$ & 0 & 1 & 0 \\
\hline \multicolumn{2}{|l|}{$\begin{array}{l}\text { LLNL background screening } \\
\text { limit }\end{array}$} & \multicolumn{2}{|c|}{1.12} & \multicolumn{2}{|c|}{8.51} & \multicolumn{2}{|c|}{308} & \multicolumn{2}{|c|}{0.62} & \multicolumn{2}{|c|}{1.59} \\
\hline & \multirow[t]{2}{*}{$\mathrm{mg} / \mathrm{kg}$} & \multicolumn{2}{|c|}{ Chromium } & \multicolumn{2}{|c|}{ Cobalt } & \multicolumn{2}{|c|}{ Copper } & \multicolumn{2}{|c|}{ Lead } & \multicolumn{2}{|c|}{ Mercury } \\
\hline & & LOS & CALC & LOS & CALC & LOS & CALC & LOS & CALC & LOS & CALC \\
\hline S-NE3-SO & $7 / 3 / 02$ & 5 & 10 & $<5$ & 0 & $<5$ & 0 & $<10$ & 0 & 0.05 & 0.1 \\
\hline S-NW2-SO DUP & $7 / 3 / 02$ & 5 & 10 & 5 & 0 & 5 & 6 & $<10$ & 0 & $<0.05$ & 0 \\
\hline S-NW2-SO RTN & $7 / 3 / 02$ & 5 & 10 & 5 & 0 & 5 & 0 & $<10$ & 0 & $<0.05$ & 0 \\
\hline S-PUMPSTN-SO & $7 / 4 / 02$ & 5 & 7 & 5 & 0 & 5 & 0 & $<10$ & 0 & $<0.05$ & 0 \\
\hline S-SE1-SO & $7 / 2 / 02$ & 5 & 9 & 5 & 0 & 5 & 0 & $<10$ & 0 & $<0.05$ & 0 \\
\hline S-SE4-SO & $7 / 4 / 02$ & 5 & 8 & 5 & 0 & 5 & 0 & $<10$ & 0 & $<0.05$ & 0 \\
\hline S-SW2-SO & $7 / 3 / 02$ & 5 & 10 & 5 & 0 & 5 & 0 & $<10$ & 0 & $<0.05$ & 0 \\
\hline S-DNWIND-SO & $7 / 4 / 02$ & 5 & 8 & 5 & 0 & $<5$ & 0 & $\mid<10$ & 0 & $<0.05$ & 0 \\
\hline S-UPWIND-SO & $7 / 4 / 02$ & 5 & 9 & 5 & 0 & $<5$ & 0 & $<10$ & 0 & $<0.05$ & 0 \\
\hline \multicolumn{2}{|c|}{$\begin{array}{l}\text { LLNL background screening } \\
\text { limit }\end{array}$} & \multicolumn{2}{|c|}{72.4} & \multicolumn{2}{|c|}{14.6} & \multicolumn{2}{|c|}{62.5} & \multicolumn{2}{|c|}{43.7} & \multicolumn{2}{|c|}{0.14} \\
\hline & $\mathrm{mg} / \mathrm{kg}$ & Molyb & denum & $\mathrm{Nic}$ & ckel & Potas & ssium & Sele & nium & Sil & Iver \\
\hline & & LOS & CALC & LOS & CALC & LOS & CALC & LOS & CALC & LOS & CALC \\
\hline S-NE3-SO & $7 / 3 / 02$ & $<5$ & 0 & $<10$ & 0 & 100 & 100 & $<2.5$ & 0 & $<2.5$ & 0 \\
\hline S-NW2-SO DUP & 7/3/02 & < & 0 & 10 & 20 & 100 & 100 & $\mid<2.5$ & 0 & $<2.5$ & 0 \\
\hline S-NW2-SO RTN & $7 / 3 / 02$ & 5 & 0 & $<10$ & 0 & 100 & 100 & $<2.5$ & 0 & $<2.5$ & 0 \\
\hline S-PUMPSTN-SO & $7 / 4 / 02$ & 5 & 0 & $<10$ & 0 & 100 & 100 & $<2.5$ & 0 & $<2.5$ & 0 \\
\hline S-SE1-SO & $7 / 2 / 02$ & 5 & 0 & $<10$ & 0 & 100 & 100 & $<2.5$ & 0 & $<2.5$ & 0 \\
\hline S-SE4-SO & $7 / 4 / 02$ & 5 & 0 & $<10$ & 0 & 100 & 100 & $<2.5$ & 0 & $<2.5$ & 0 \\
\hline S-SW2-SO & $7 / 3 / 02$ & 5 & 0 & $<10$ & 0 & 100 & 200 & $<2.5$ & 0 & $<2.5$ & 0 \\
\hline S-DNWIND-SO & $7 / 4 / 02$ & 5 & 0 & $<10$ & 0 & 100 & 200 & $<2.5$ & 0 & $<2.5$ & 0 \\
\hline S-UPWIND-SO & $7 / 4 / 02$ & 5 & 0 & $<10$ & 0 & 100 & 200 & $<2.5$ & 0 & $<2.5$ & 0 \\
\hline $\begin{array}{l}\text { LLNL background screening } \\
\text { limit }\end{array}$ & & any $d \epsilon$ & tection & & 32.8 & & na & any de & etection & any de & etection \\
\hline
\end{tabular}


Table 3. Metals analysis for soils (continued)

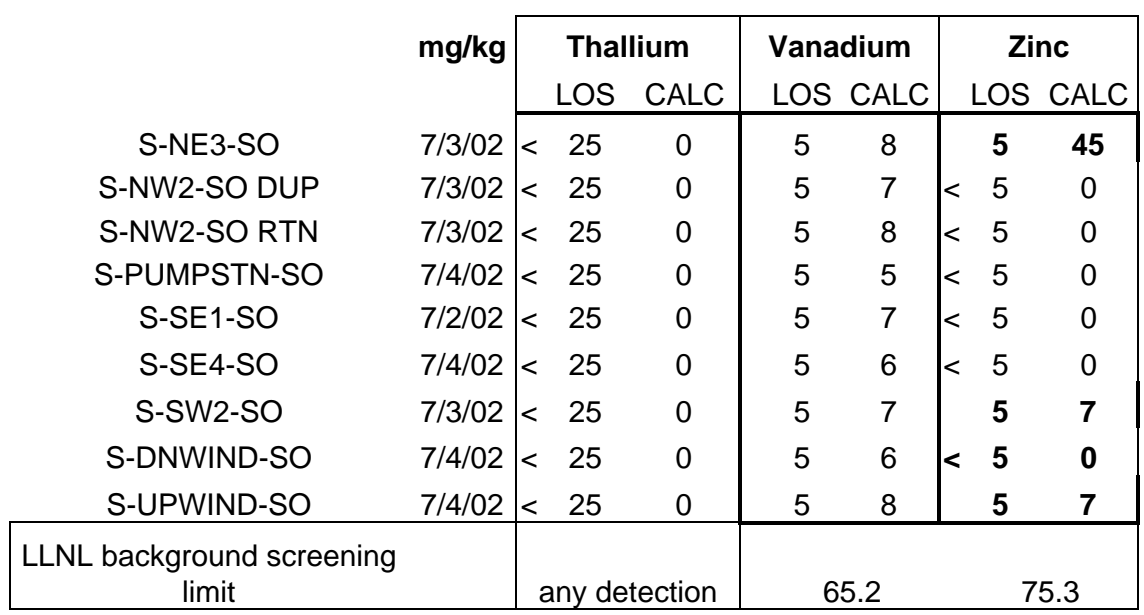

All non detects except bolded data

LOS= Limit of sensitivity ( minimum detection limit)

$\mathrm{CALC}=$ calculated positive detection 
Table 4. Pesticides in vegetation

\begin{tabular}{|c|c|c|c|c|c|c|c|c|c|c|c|c|c|}
\hline \multirow[t]{2}{*}{ E8081 } & \multirow[t]{2}{*}{$\mathrm{mg} / \mathrm{kg}$} & \multicolumn{3}{|c|}{ Aldrin } & \multicolumn{3}{|c|}{ BHC, alpha isomer } & \multicolumn{3}{|c|}{ BHC, beta isomer } & \multicolumn{3}{|c|}{ BHC, delta isomer } \\
\hline & & dilution & LOS & CALC & dilution & LOS & CALC & dilution & LOS & CALC & dilution & LOS & CALC \\
\hline S-DNWIND-VG & $7 / 4 / 02$ & 2 & $<0.012$ & 0 & 2 & $<0.012$ & 0 & 2 & $<0.012$ & 0 & 2 & $<0.018$ & 0 \\
\hline S-NE3-VG & $7 / 3 / 02$ & 2 & $<0.024$ & 0 & 2 & $<0.024$ & 0 & 2 & $<0.024$ & 0 & 2 & $<0.036$ & 0 \\
\hline S-NW2-VG RTN & $7 / 3 / 02$ & 2 & $<0.024$ & 0 & 2 & $<0.024$ & 0 & 2 & $<0.024$ & 0 & 2 & $<0.036$ & 0 \\
\hline S-NW2-VG DUP & $7 / 3 / 02$ & 2 & $<0.024$ & 0 & 2 & $<0.024$ & 0 & 2 & $<0.024$ & 0 & 2 & $<0.036$ & 0 \\
\hline S-PUMPSTN-VG & $7 / 4 / 02$ & 2 & $<0.024$ & 0 & 2 & $<0.024$ & 0 & 2 & $<0.024$ & 0 & 2 & $<0.036$ & 0 \\
\hline S-SE1-VG & $7 / 2 / 02$ & 2 & $<0.024$ & 0 & 2 & $<0.024$ & 0 & 2 & $<0.024$ & 0 & 2 & $<0.036$ & 0 \\
\hline S-SE4-VG & $7 / 4 / 02$ & 1 & $<0.012$ & 0 & 1 & $<0.012$ & 0 & 1 & $<0.012$ & 0 & 1 & $<0.018$ & 0 \\
\hline S-SW2-VG & $7 / 3 / 02$ & 2 & $<0.024$ & 0 & 2 & $<0.024$ & 0 & 2 & $<0.024$ & 0 & 2 & $<0.036$ & 0 \\
\hline S-UPWIND-VG & 7/4/02 & 2 & $<0.015$ & 0 & 2 & $<0.015$ & 0 & 2 & $<0.015$ & 0 & 2 & $<0.023$ & 0 \\
\hline
\end{tabular}

\begin{tabular}{|c|c|c|c|c|c|c|c|c|c|c|c|c|c|}
\hline & & $\begin{array}{r}\text { BHC, } g \\
(1\end{array}$ & $\begin{array}{l}\text { gamma is } \\
\text { (Lindane) }\end{array}$ & somer & & hlordan & & & Dieldrin & & End & dosulfan & \\
\hline & & dilution & LOS & CALC & dilution & LOS & CALC & dilution & LOS & CALC & dilution & LOS C & SALC \\
\hline S-DNWIND-VG & $7 / 4 / 02$ & 2 & $<0.012$ & 0 & 2 & $<0.03$ & 0 & 2 & $<0.012$ & 0 & 2 & $<0.012$ & 0 \\
\hline S-NE3-VG & $7 / 3 / 02$ & 2 & $<0.024$ & 0 & 2 & $<0.06$ & 0 & 2 & $<0.024$ & 0 & 2 & $<0.024$ & 0 \\
\hline S-NW2-VG RTN & $7 / 3 / 02$ & 2 & $<0.024$ & 0 & 2 & $<0.06$ & 0 & 2 & $<0.024$ & 0 & 2 & $<0.024$ & 0 \\
\hline S-NW2-VG DUP & $7 / 3 / 02$ & 2 & $<0.024$ & 0 & 2 & $<0.06$ & 0 & 2 & $<0.024$ & 0 & 2 & $<0.024$ & 0 \\
\hline S-PUMPSTN-VG & $7 / 4 / 02$ & 2 & $<0.024$ & 0 & 2 & $<0.06$ & 0 & 2 & $<0.024$ & 0 & 2 & $<0.024$ & 0 \\
\hline S-SE1-VG & $7 / 2 / 02$ & 2 & $<0.024$ & 0 & 2 & $<0.06$ & 0 & 2 & $<0.024$ & 0 & 2 & $<0.024$ & 0 \\
\hline S-SE4-VG & $7 / 4 / 02$ & 1 & $<0.012$ & 0 & 1 & $<0.03$ & 0 & 1 & $<0.012$ & 0 & 1 & $<0.012$ & 0 \\
\hline S-SW2-VG & $7 / 3 / 02$ & 2 & $<0.024$ & 0 & 2 & $<0.06$ & 0 & 2 & $<0.024$ & 0 & 2 & $<0.024$ & 0 \\
\hline S-UPWIND-VG & $7 / 4 / 02$ & 2 & $<0.015$ & 0 & 2 & $<0.038$ & 0 & 2 & $<0.015$ & 0 & 2 & $<0.015$ & 0 \\
\hline & & & idosulfan & & Endos & sulfan st & ulfate & & Endrin & & Endri & in aldehy & \\
\hline & & dilution & LOS & CALC & dilution & LOS & CALC & dilution & LOS & CALC & dilution & LOS C & SALC \\
\hline S-DNWIND-VG & $7 / 4 / 02$ & 2 & $<0.012$ & 0 & 2 & $<0.012$ & 0 & 2 & $<0.012$ & 0 & 2 & $<0.012$ & 0 \\
\hline S-NE3-VG & $7 / 3 / 02$ & 2 & $<0.024$ & 0 & 2 & $<0.024$ & 0 & 2 & $<0.024$ & 0 & 2 & $<0.024$ & 0 \\
\hline S-NW2-VG RTN & $7 / 3 / 02$ & 2 & $<0.024$ & 0 & 2 & $<0.024$ & 0 & 2 & $<0.024$ & 0 & 2 & $<0.024$ & 0 \\
\hline S-NW2-VG DUP & $7 / 3 / 02$ & 2 & $<0.024$ & 0 & 2 & $<0.024$ & 0 & 2 & $<0.024$ & 0 & 2 & $<0.024$ & 0 \\
\hline S-PUMPSTN-VG & $7 / 4 / 02$ & 2 & $<0.024$ & 0 & 2 & $<0.024$ & 0 & 2 & $<0.024$ & 0 & 2 & $<0.024$ & 0 \\
\hline S-SE1-VG & 7/2/02 & 2 & $<0.024$ & 0 & 2 & $<0.024$ & 0 & 2 & $<0.024$ & 0 & 2 & $<0.024$ & 0 \\
\hline S-SE4-VG & $7 / 4 / 02$ & 1 & $<0.012$ & 0 & 1 & $<0.012$ & 0 & 1 & $<0.012$ & 0 & 1 & $<0.012$ & 0 \\
\hline S-SW2-VG & $7 / 3 / 02$ & 2 & $<0.024$ & 0 & 2 & $<0.024$ & 0 & 2 & $<0.024$ & 0 & 2 & $<0.024$ & 0 \\
\hline S-UPWIND-VG & 7/4/02 & 2 & $<0.015$ & 0 & 2 & $<0.015$ & 0 & 2 & $<0.015$ & 0 & 2 & $<0.015$ & 0 \\
\hline
\end{tabular}


Table 4. Pesticides in vegetation (continued)

\begin{tabular}{|c|c|c|c|c|c|c|c|c|c|c|c|c|c|}
\hline & & & eptachlo & & Heptac & chlor ep & xide & Metr & thoxych & & & o,p-DDD & \\
\hline & & dilution & LOS & CALC & dilution & LOS & SALC & dilution & LOS & CALCC & dilution & LOS & ALC \\
\hline S-DNWIND-VG & $7 / 4 / 02$ & 2 & $<0.012$ & 0 & 2 & $<0.012$ & 0 & 2 & $<0.012$ & 0 & 2 & $<0.012$ & 0 \\
\hline S-NE3-VG & $7 / 3 / 02$ & 2 & $<0.024$ & 0 & 2 & $<0.024$ & 0 & 2 & $<0.024$ & 0 & 2 & $<0.024$ & 0 \\
\hline S-NW2-VG RTN & $7 / 3 / 02$ & 2 & $<0.024$ & 0 & 2 & $<0.024$ & 0 & 2 & $<0.024$ & 0 & 2 & $<0.024$ & 0 \\
\hline S-NW2-VG DUP & $7 / 3 / 02$ & 2 & $<0.024$ & 0 & 2 & $<0.024$ & 0 & 2 & $<0.024$ & 0 & 2 & $<0.024$ & 0 \\
\hline S-PUMPSTN-VG & $7 / 4 / 02$ & 2 & $<0.024$ & 0 & 2 & $<0.024$ & 0 & 2 & $<0.024$ & 0 & 2 & $<0.024$ & 0 \\
\hline S-SE1-VG & $7 / 2 / 02$ & 2 & $<0.024$ & 0 & 2 & $<0.024$ & 0 & 2 & $<0.024$ & 0 & 2 & $<0.024$ & 0 \\
\hline S-SE4-VG & $7 / 4 / 02$ & 1 & $<0.012$ & 0 & 1 & $<0.012$ & 0 & 1 & $<0.012$ & 0 & 1 & $<0.012$ & 0 \\
\hline S-SW2-VG & $7 / 3 / 02$ & 2 & $<0.024$ & 0 & 2 & $<0.024$ & 0 & 2 & $<0.024$ & 0 & 2 & $<0.024$ & 0 \\
\hline S-UPWIND-VG & $7 / 4 / 02$ & 2 & $<0.015$ & 0 & 2 & $<0.015$ & 0 & 2 & $<0.015$ & 0 & 2 & $<0.015$ & 0 \\
\hline & & & p,p-DDE & & & p,p-DDT & & & oxaphen & & & & \\
\hline & & dilution & LOS & CALC & dilution & LOS & SALC & dilution & LOS & CALC & & & \\
\hline S-DNWIND-VG & $7 / 4 / 02$ & 2 & $<0.012$ & 0 & 2 & $<0.012$ & 0 & 2 & $<0.12$ & 0 & & & \\
\hline S-NE3-VG & $7 / 3 / 02$ & 2 & $<0.024$ & 0 & 2 & $<0.024$ & 0 & 2 & $<0.24$ & 0 & & & \\
\hline S-NW2-VG RTN & $7 / 3 / 02$ & 2 & $<0.024$ & 0 & 2 & $<0.024$ & 0 & 2 & $<0.24$ & 0 & & & \\
\hline S-NW2-VG DUP & $7 / 3 / 02$ & 2 & $<0.024$ & 0 & 2 & $<0.024$ & 0 & 2 & $<0.24$ & 0 & & & \\
\hline S-PUMPSTN-VG & $7 / 4 / 02$ & 2 & $<0.024$ & 0 & 2 & $<0.024$ & 0 & 2 & $<0.24$ & 0 & & & \\
\hline S-SE1-VG & 7/2/02 & 2 & $<0.024$ & 0 & 2 & $<0.024$ & 0 & 2 & $<0.24$ & 0 & & & \\
\hline S-SE4-VG & $7 / 4 / 02$ & 1 & $<0.012$ & 0 & 1 & $<0.012$ & 0 & 1 & $<0.12$ & 0 & & & \\
\hline S-SW2-VG & $7 / 3 / 02$ & 2 & $<0.024$ & 0 & 2 & $<0.024$ & 0 & 2 & $<0.24$ & 0 & & & \\
\hline S-UPWIND-VG & $7 / 4 / 02$ & 2 & $<0.015$ & 0 & 2 & $<0.015$ & 0 & 2 & $<0.15$ & 0 & & & \\
\hline
\end{tabular}

All non detects

LOS= Limit of sensitivity (minimum detection limit)

$\mathrm{CALC}=$ calculated positive detection 
Table 5. Metals in vegetation

\begin{tabular}{|c|c|c|c|c|c|c|c|c|c|c|c|}
\hline \multirow[t]{2}{*}{ TTLCMB+K } & \multirow[t]{2}{*}{$\mathbf{m g} / \mathbf{k g}$} & \multicolumn{2}{|c|}{ Antimony } & \multicolumn{2}{|c|}{ Arsenic } & \multicolumn{2}{|c|}{ Barium } & \multirow{2}{*}{\multicolumn{2}{|c|}{$\begin{array}{l}\text { Beryllium } \\
\text { LOS CALC }\end{array}$}} & \multirow{2}{*}{\multicolumn{2}{|c|}{$\begin{array}{l}\text { Cadmium } \\
\text { LOS CALC }\end{array}$}} \\
\hline & & LOS & CALC & \multicolumn{2}{|c|}{ LOS CALC } & \multirow{2}{*}{$\frac{\text { LOS }}{5}$} & \multirow{2}{*}{$\frac{\text { CALC }}{9}$} & & & & \\
\hline S-DNWIND-VG & $7 / 4 / 02$ & 1 & 0 & 0.5 & 1 & & & $<0.5$ & 0 & $<1$ & 0 \\
\hline S-NE3-VG & $7 / 3 / 02$ & $<$ & 0 & $<0.5$ & 0 & 5 & 25 & $<0.5$ & 0 & $<1$ & 0 \\
\hline S-NW2-VG RTN & $7 / 3 / 02$ & 1 & 0 & 0.5 & 0.7 & 5 & 36 & $<0.5$ & 0 & $<1$ & 0 \\
\hline S-NW2-VG DUP & $7 / 3 / 02$ & 1 & 0 & $<0.5$ & 0 & 5 & 34 & $<0.5$ & 0 & $\mid<1$ & 0 \\
\hline S-PUMPSTN-VG & $7 / 4 / 02$ & 1 & 0 & $<0.5$ & 0 & 5 & 29 & $<0.5$ & 0 & $<1$ & 0 \\
\hline S-SE1-VG & 7/2/02 & 1 & 0 & $<0.5$ & 0 & 5 & 34 & $<0.5$ & 0 & $\mid<1$ & 0 \\
\hline S-SE4-VG & $7 / 4 / 02$ & 1 & 0 & $<0.5$ & 0 & 5 & 36 & $<0.5$ & 0 & $<1$ & 0 \\
\hline S-SW2-VG & $7 / 3 / 02$ & $<$ & 0 & 0.5 & 0.7 & 5 & 24 & $<0.5$ & 0 & $<1$ & 0 \\
\hline \multirow[t]{3}{*}{ S-UPWIND-VG } & $7 / 4 / 02$ & $<$ & 0 & 0.5 & 0.8 & 5 & 14 & $<0.5$ & 0 & $<1$ & 0 \\
\hline & & \multicolumn{2}{|c|}{ Chromium } & \multicolumn{2}{|c|}{ Cobalt } & \multicolumn{2}{|c|}{ Copper } & \multicolumn{2}{|c|}{ Lead (a) } & \multicolumn{2}{|c|}{ Mercury } \\
\hline & & \multicolumn{2}{|c|}{ LOS CALC } & \multicolumn{2}{|c|}{ LOS CALC } & LOS & CALC & \multicolumn{2}{|c|}{ LOS CALC } & \multicolumn{2}{|c|}{ LOS CALC } \\
\hline S-DNWIND-VG & $7 / 4 / 02$ & 5 & 0 & $<5$ & 0 & 5 & 7 & $<10$ & 0 & $<0.1$ & 0 \\
\hline S-NE3-VG & $7 / 3 / 02$ & $<$ & 0 & $<5$ & 0 & 5 & 0 & $<10$ & 0 & $<0.1$ & 0 \\
\hline S-NW2-VG RTN & $7 / 3 / 02$ & $<$ & 0 & 5 & 0 & 5 & 5 & 20 & 1700 & $<0.1$ & 0 \\
\hline S-NW2-VG DUP & $7 / 3 / 02$ & $<$ & 0 & $<5$ & 0 & 5 & 0 & 10 & 80 & $<0.1$ & 0 \\
\hline S-PUMPSTN-VG & $7 / 4 / 02$ & $<$ & 0 & $<5$ & 0 & 5 & 0 & $<10$ & 0 & $<0.1$ & 0 \\
\hline S-SE1-VG & 7/2/02 & $<$ & 0 & $<5$ & 0 & 5 & 0 & $<10$ & 0 & $<0.1$ & 0 \\
\hline S-SE4-VG & $7 / 4 / 02$ & $<$ & 0 & $<5$ & 0 & 5 & 0 & $<10$ & 0 & $<0.1$ & 0 \\
\hline S-SW2-VG & $7 / 3 / 02$ & $<$ & 0 & $<5$ & 0 & 5 & 0 & $<10$ & 0 & $<0.1$ & 0 \\
\hline \multirow[t]{3}{*}{ S-UPWIND-VG } & $7 / 4 / 02$ & $<$ & 0 & $<5$ & 0 & 5 & 7 & $<10$ & 0 & $<0.1$ & 0 \\
\hline & & \multicolumn{2}{|c|}{ Molybdenum } & \multicolumn{2}{|c|}{ Nickel } & \multicolumn{2}{|c|}{ Potassium (b) } & \multicolumn{2}{|c|}{ Selenium } & \multicolumn{2}{|c|}{ Silver } \\
\hline & & LOS & CALC & LOS & JALC & LOS & CALC & LOS & CALC & LOS & CALC \\
\hline S-DNWIND-VG & $7 / 4 / 02$ & $<$ & 0 & $<10$ & 0 & 100 & 600 & $<2.5$ & 0 & $<2.5$ & 0 \\
\hline S-NE3-VG & $7 / 3 / 02$ & $<$ & 0 & $<10$ & 0 & 200 & 4500 & $<2.5$ & 0 & $<2.5$ & 0 \\
\hline S-NW2-VG RTN & $7 / 3 / 02$ & $<$ & 0 & $<10$ & 0 & 200 & 9000 & $<2.5$ & 0 & $<2.5$ & 0 \\
\hline S-NW2-VG DUP & $7 / 3 / 02$ & $<$ & 0 & $<10$ & 0 & 200 & 8800 & $<2.5$ & 0 & $<2.5$ & 0 \\
\hline S-PUMPSTN-VG & $7 / 4 / 02$ & $<$ & 0 & $<10$ & 0 & 200 & 5600 & $<2.5$ & 0 & $<2.5$ & 0 \\
\hline S-SE1-VG & 7/2/02 & $<$ & 0 & $<10$ & 0 & 200 & 5300 & $<2.5$ & 0 & $<2.5$ & 0 \\
\hline S-SE4-VG & $7 / 4 / 02$ & $<$ & 0 & $<10$ & 0 & 200 & 7700 & $<2.5$ & 0 & $<2.5$ & 0 \\
\hline S-SW2-VG & $7 / 3 / 02$ & $<$ & 0 & $<10$ & 0 & 200 & 8700 & $<2.5$ & 0 & $<2.5$ & 0 \\
\hline S-UPWIND-VG & $7 / 4 / 02$ & 5 & 0 & $<10$ & 0 & 100 & 700 & $<2.5$ & 0 & $<2.5$ & 0 \\
\hline
\end{tabular}


Table 5. Metals in vegetation (continued)

\begin{tabular}{|c|c|c|c|c|c|c|c|}
\hline \multirow[b]{2}{*}{ S-DNWIND-VG } & \multirow[b]{2}{*}{$7 / 4 / 02$} & \multicolumn{2}{|c|}{ Thallium } & \multicolumn{2}{|c|}{ Vanadium } & \multicolumn{2}{|c|}{ Zinc } \\
\hline & & LOS & CALC & LOS & ALC & LOS & CALC \\
\hline S-NE3-VG & 7/3/02 & $<25$ & 0 & $<5$ & 0 & 5 & 8 \\
\hline S-NW2-VG RTN & $7 / 3 / 02$ & $<25$ & 0 & $<5$ & 0 & 5 & 65 \\
\hline S-NW2-VG DUP & $7 / 3 / 02$ & $<25$ & 0 & 5 & 0 & 5 & 33 \\
\hline S-PUMPSTN-VG & $7 / 4 / 02$ & $<25$ & 0 & 5 & 0 & 5 & 15 \\
\hline S-SE1-VG & $7 / 2 / 02$ & $<25$ & 0 & $<5$ & 0 & 5 & 17 \\
\hline S-SE4-VG & $7 / 4 / 02$ & $<25$ & 0 & $<5$ & 0 & 5 & 12 \\
\hline S-SW2-VG & $7 / 3 / 02$ & $<25$ & 0 & $<5$ & 0 & 5 & 17 \\
\hline \multirow[t]{2}{*}{ S-UPWIND-VG } & $7 / 4 / 02$ & $<25$ & 0 & $<5$ & 0 & 5 & 27 \\
\hline & & $<25$ & 0 & $<5$ & 0 & 5 & 9 \\
\hline
\end{tabular}

a dilution 2

b dilution 10

All non detections except bolded areas

LOS= limit of sensitivity ( minimum detection limit)

$\mathrm{CALC}=$ calculated positive detection 
Table 6. Number of metal detections in soils and vegetation

\begin{tabular}{lccc}
\hline Analyte & $\begin{array}{c}\text { Number of detections } \\
\text { in soil }\end{array}$ & $\begin{array}{c}\text { Number of detections in short- } \\
\text { lived vegetation }\end{array}$ & $\begin{array}{c}\text { Number of } \\
\text { samples }\end{array}$ \\
\hline Antimony & 0 & 0 & 6 \\
Arsenic & 6 & 2 & 6 \\
Barium & 6 & 6 & 6 \\
Beryllium & 0 & 0 & 6 \\
Cadmium & 0 & 0 & 6 \\
Chromium & 6 & 0 & 6 \\
Cobalt & 0 & 0 & 6 \\
Copper & 0 & 1 & 6 \\
Lead & 0 & 2 & 6 \\
Mercury & 1 & 0 & 6 \\
Molybdenum & 0 & 0 & 6 \\
Nickel & 0 & 0 & 6 \\
Potassium & 6 & 6 & 6 \\
Selenium & 0 & 0 & 6 \\
Silver & 0 & 0 & 6 \\
Thallium & 0 & 0 & 6 \\
Vanadium & 6 & 0 & 6 \\
Zinc & 2 & 6 & 6 \\
\hline
\end{tabular}




\section{Table 7. NPDES metals analysis in water}

\begin{tabular}{|c|c|c|c|c|c|c|c|c|c|c|c|c|c|c|}
\hline \multirow[t]{2}{*}{ NPDESMETAL } & & & \multicolumn{2}{|c|}{ Aluminum } & \multicolumn{2}{|c|}{ Antimony } & \multicolumn{3}{|c|}{ Arsenic } & \multicolumn{2}{|c|}{ Barium } & \multicolumn{3}{|c|}{ Beryllium } \\
\hline & \multirow[b]{2}{*}{$7 / 4 / 02$} & \multirow[b]{2}{*}{$\mathrm{mg} / \mathrm{L}$} & \multicolumn{2}{|c|}{ LOS CALC } & dilution & CALC & dilution & LOS & CALC & LOS & CALC & dilution & LOS & CALC \\
\hline S-DISCHGE-OW & & & 0.1 & 0.7 & & & & & & 0.025 & 0.081 & & & \\
\hline S-DISCHGE-OW & $7 / 4 / 02$ & $2 \mu \mathrm{g} / \mathrm{L}$ & & & $<5$ & 0 & 5 & 5 & 44 & & & 5 & $<0.5$ & 0 \\
\hline S-ENSO6Z5-OW & $7 / 4 / 02$ & $2 \mathrm{mg} / \mathrm{L}$ & $<0.1$ & 0 & & & & & & 0.025 & 0.033 & & & \\
\hline S-ENSO6Z5-OW & $7 / 4 / 02$ & $\mu \mathrm{g} / \mathrm{L}$ & & & $<5$ & 0 & 1 & $<2$ & 0 & & & 1 & $<0.2$ & 0 \\
\hline S-ENSO9ZO-OW DUP & $7 / 4 / 02$ & $2 \mathrm{mg} / \mathrm{L}<$ & $<0.05$ & 0 & $<0.00$ & 0 & 1 & $<0.002$ & 0 & 0.025 & 0.03 & 1 & $<0.0002$ & 0 \\
\hline S-ENSO9Z0-OW RTN & $7 / 4 / 02$ & $2 \mathrm{mg} / \mathrm{L}$ & $<0.1$ & 0 & & & & & & 0.025 & 0.026 & & & \\
\hline S-ENSO9Z0-OW RTN & $7 / 4 / 02$ & $\mu \mathrm{g} / \mathrm{L}$ & & & $<5$ & 0 & 1 & $<2$ & 0 & & & 1 & $<0.2$ & 0 \\
\hline \multicolumn{3}{|c|}{ Maximum discharge values* $\mathrm{mg} / \mathrm{L}$} & \multicolumn{2}{|l|}{ NA } & NA & & & 0.1 & & 1. & .0 & & NA & \\
\hline NPDESMETAL & & & & & Boron & & Cadmium & & & Chron & mium & & Cobc & \\
\hline & & & & LOS & CALC & dilution & LOS & CALC & dilutio & on $\quad \mathrm{LO}$ & & CALC & LOS & CALC \\
\hline S-DISCHGE-OW & & $7 / 4 / 02$ & $\mathrm{mg} / \mathrm{L}$ & 0.1 & 3.6 & & & & & & & & $<0.05$ & 0 \\
\hline S-DISCHGE-OW & & $7 / 4 / 02$ & $\mu \mathrm{g} / \mathrm{L}$ & & & 5 & $<0.5$ & 0 & 5 & $<2$ & 2.5 & 0 & & \\
\hline S-ENSO6Z5-OW & & $7 / 4 / 02$ & $\mathrm{mg} / \mathrm{L}$ & $<0.1$ & 0 & & & & & & & & $<0.05$ & 0 \\
\hline S-ENSO6Z5-OW & & $7 / 4 / 02$ & $\mu \mathrm{g} / \mathrm{L}$ & & & 1 & $<0.5$ & 0 & 1 & $<1$ & 1 & 0 & & \\
\hline S-ENSO9Z0-OW DUP & & $7 / 4 / 02$ & $\mathrm{mg} / \mathrm{L}$ & 0.05 & 0.073 & 1 & 0.0005 & 0 & 1 & $<0.0$ & 001 & 0 & $<0.05$ & 0 \\
\hline S-ENSO9Z0-OW RTN & & $7 / 4 / 02$ & $\mathrm{mg} / \mathrm{L}$ & $<0.1$ & 0 & & & & & & & & $<0.05$ & 0 \\
\hline S-ENSO9ZO-OW RTN & & $7 / 4 / 02$ & $\mu g / L$ & & & 1 & $<0.5$ & 0 & 1 & $<1$ & 1 & 0 & & \\
\hline Maximum discharg & ge value & $1 \mathrm{es}{ }^{*} \mathrm{mg} / \mathrm{L}$ & & & NA & & 0.2 & & & 2.0 & 0 & & 0.5 & \\
\hline NPDESMETAL & & & & & Copper & & $\begin{array}{l}\text { Hexav } \\
\text { Chrom }\end{array}$ & $\begin{array}{l}\text { alent } \\
\text { ium }\end{array}$ & & Iron & & & Lead & \\
\hline & & & & dilution & LOS & CALC & LOS & CALC & LOS & CALC & & ution & LOS & CALC \\
\hline S-DISCHGE-OW & & $7 / 4 / 02$ & $\mathrm{mg} / \mathrm{L}$ & & & & & & 0.1 & 0.4 & & & & \\
\hline S-DISCHGE-OW & & $7 / 4 / 02$ & $\mu g / L$ & 5 & 5 & 9 & & & & & & 5 & $<5$ & 0 \\
\hline S-ENSO6Z5-OW & & $7 / 4 / 02$ & $\mathrm{mg} / \mathrm{L}$ & & & & & & $<0.1$ & 0 & & & & \\
\hline S-ENSO6Z5-OW & & $7 / 4 / 02$ & $\mu \mathrm{g} / \mathrm{L}$ & 1 & $<1$ & 0 & & & & & & 1 & $<5$ & 0 \\
\hline S-ENSO9Z0-OW DUP & & $7 / 4 / 02$ & $\mathrm{mg} / \mathrm{L}$ & 1 & 0.001 & 0.0024 & $<0.002$ & 0 & $<0.1$ & 0 & & $<$ & $<0.005$ & 0 \\
\hline S-ENSO9ZO-OW RTN & & $7 / 4 / 02$ & $\mathrm{mg} / \mathrm{L}$ & & & & & & $<0.1$ & 0 & & & & \\
\hline S-ENSO9ZO-OW RTN & & $7 / 4 / 02$ & $\mu g / L$ & 1 & 1 & 3 & & & & & & 1 & $<5$ & 0 \\
\hline Maximum discharge & ge value & $\mathrm{es}^{*} \mathrm{mg} / \mathrm{L}$ & & & NA & & 2.0 & & & 3.0 & & & 0.5 & \\
\hline NPDESMETAL & & & Man & Inganese & Merc & sury & Molybd & enum & & Nickel & & & Selenium & \\
\hline & & & LOS & CAL & LOS & CALC & LOS & CALC & dilution & LOS & CALC & dilution & $\begin{array}{ll}\mathrm{n} \quad \mathrm{LOS} \\
\end{array}$ & CALC \\
\hline S-DISCHGE-OW & $7 / 4 / 0$ & $02 \mathrm{mg} / \mathrm{L}$ & L $<0.03$ & 0 & & & $<0.025$ & 0 & & & & & & \\
\hline S-DISCHGE-OW & $7 / 4 / 0$ & $02 \mu \mathrm{g} / \mathrm{L}$ & & & $<0.2$ & 0 & & & 5 & 5 & 15 & 5 & 5 & 21 \\
\hline S-ENSO6Z5-OW & $7 / 4 / 0$ & $02 \mathrm{mg} / \mathrm{L}$ & $L<0.03$ & 0 & & & $<0.025$ & 0 & & & & & & \\
\hline S-ENSO6Z5-OW & $7 / 4 / 0$ & $02 \mu \mathrm{g} / \mathrm{L}$ & & & $<0.2$ & 0 & & & 1 & $<5$ & 0 & 1 & $<5$ & 0 \\
\hline S-ENSO9Z0-OW DUP & $7 / 4 / 0$ & $02 \mathrm{mg} / \mathrm{L}$ & $-<0.03$ & 0 & $<0.0002$ & 0 & $<0.025$ & 0 & 1 & 0.002 & 0.0038 & 1 & $<0.002$ & 0 \\
\hline S-ENSO9ZO-OW RTN & $7 / 4 / 0$ & $\mathrm{mg} / \mathrm{L}$ & $-<0.03$ & 0 & & & $<0.025$ & 0 & & & & & & \\
\hline S-ENSO9Z0-OW RTN & $7 / 4 / 0$ & $02 \mu \mathrm{g} / \mathrm{L}$ & & & $<0.2$ & 0 & & & 1 & $<5$ & 0 & 1 & $<5$ & 0 \\
\hline Maximum discharge ve & values* & $\mathrm{mg} / \mathrm{L}$ & & 1.0 & .0 & & $\mathrm{NA}$ & & & 0.5 & & & 0.1 & \\
\hline
\end{tabular}


Table 7. NPDES metals analysis in water (continued)

\begin{tabular}{|c|c|c|c|c|c|c|c|c|c|c|c|c|}
\hline \multirow{2}{*}{ NPDESMETAL } & & & \multicolumn{3}{|c|}{ Silver } & \multicolumn{3}{|c|}{ Thallium } & \multicolumn{2}{|c|}{ Vanadium } & \multicolumn{2}{|c|}{ Zinc } \\
\hline & & & dilution & LOS & CALC & dilution & LOS & CALC & LOS & CALC & LOS & CALO \\
\hline S-DISCHGE-OW & $7 / 4 / 02$ & $\mathrm{mg} / \mathrm{L}$ & & & & & & & $<0.02$ & 0 & $<0.02$ & 0 \\
\hline S-DISCHGE-OW & $7 / 4 / 02$ & $\mu \mathrm{g} / \mathrm{L}$ & 5 & $<1$ & 0 & 5 & $<5$ & 0 & & & & \\
\hline S-ENSO6Z5-OW & $7 / 4 / 02$ & $\mathrm{mg} / \mathrm{L}$ & & & & & & & $<0.02$ & 0 & $<0.02$ & 0 \\
\hline S-ENSO6Z5-OW & $7 / 4 / 02$ & $\mu g / L$ & 1 & $<1$ & 0 & 1 & $<1$ & 0 & & & & \\
\hline S-ENSO9Z0-OW DUP & $7 / 4 / 02$ & $\mathrm{mg} / \mathrm{L}$ & 1 & $<0.001$ & 0 & 1 & $<0.001$ & 0 & $<0.02$ & 0 & $<0.02$ & 0.32 \\
\hline S-ENSO9Z0-OW RTN & $7 / 4 / 02$ & $\mathrm{mg} / \mathrm{L}$ & & & & & & & $<0.02$ & 0 & $<0.02$ & 0.77 \\
\hline S-ENSO9Z0-OW RTN & $7 / 4 / 02$ & $\mu \mathrm{g} / \mathrm{L}$ & 1 & $<1$ & 0 & 1 & $<1$ & 0 & & & & \\
\hline \multicolumn{3}{|c|}{ Maximum discharge values ${ }^{\star} \mathrm{mg} / \mathrm{L}$} & \multicolumn{3}{|c|}{0.1} & \multicolumn{3}{|c|}{ NA } & \multicolumn{2}{|c|}{ NA } & \multicolumn{2}{|c|}{5.0} \\
\hline
\end{tabular}

Note:

* Maximum value for direct discharge (Morocco Ministry of Environment). http://www.minenv.gov.ma/projets/fodep/TDRFOD2.htm 


\section{Table 8. General minerals analysis in water}

\begin{tabular}{|c|c|c|c|c|c|c|c|c|c|c|c|c|c|c|c|}
\hline \multirow[t]{2}{*}{$\begin{array}{c}\text { GENMIN } \\
\text { (General Minerals) }\end{array}$} & \multirow[t]{2}{*}{$\mathrm{mg} / \mathrm{L}$} & \multicolumn{2}{|c|}{ Aluminum } & \multicolumn{3}{|c|}{$\begin{array}{l}\text { Bicarbonate Alk } \\
\left.\text { (as } \mathrm{CaCO}_{3}\right)\end{array}$} & \multicolumn{3}{|c|}{ Calcium } & \multicolumn{3}{|c|}{$\begin{array}{l}\text { Carbonate Alk } \\
\left.\text { (as } \mathrm{CaCO}_{3}\right)\end{array}$} & \multicolumn{3}{|c|}{ Chloride } \\
\hline & & LOS & CALC & dilution & LOS & CALC & dilution & LOS & CALC & dilution & LOS & CALC & dilution & LOS & CALC \\
\hline S-DISCHGE-OW & $7 / 4 / 02$ & $<0.2$ & 0.7 & 1 & 1 & 150 & 4 & 2 & 280 & 1 & $<1$ & 0 & 100 & 50 & 13000 \\
\hline S-ENSO6Z5-OW & $7 / 4 / 02$ & $<0.2$ & 0 & 1 & 1 & 350 & 2 & 1 & 130 & 1 & $<1$ & 0 & 10 & 5 & 66 \\
\hline S-ENSO9ZO-OW DUP & $7 / 4 / 02$ & $<0.05$ & 0 & 2 & 5 & 280 & 1 & 0.5 & 86 & 2 & $<5$ & 0 & 1 & 0.5 & 43 \\
\hline S-ENSO9ZO-OW RTN & $7 / 4 / 02$ & $<0.2$ & 0 & 1 & 1 & 270 & 1 & 0.5 & 94 & 1 & $<1$ & 0 & 10 & 5 & 55 \\
\hline Maximum discharge valu & ${ }^{*} \mathrm{mg} / \mathrm{L}$ & 10 & 0.0 & & NA & & & NA & & & NA & & & NA & \\
\hline
\end{tabular}

\begin{tabular}{|c|c|c|c|c|c|c|c|c|c|c|c|c|c|}
\hline \multirow[t]{2}{*}{ GENMIN } & \multirow[t]{2}{*}{$\mathrm{mg} / \mathrm{L}$} & \multicolumn{2}{|c|}{ Copper } & \multicolumn{2}{|c|}{ Fluoride } & \multicolumn{3}{|c|}{$\begin{array}{l}\text { Hydroxide Alk } \\
\text { (as }\left(\mathrm{CaCO}_{3}\right)\end{array}$} & \multicolumn{2}{|c|}{ Iron } & \multicolumn{3}{|c|}{ Magnesium } \\
\hline & & LOS & CALC & LOS & CALC & dilution & LOS & CALC & LOS & CALC & dilution & LOS & CALC \\
\hline S-DISCHGE-OW & $7 / 4 / 02$ & $<0.05$ & 0 & 0.05 & 0.11 & 1 & 1 & 0 & & & 10 & 5 & 880 \\
\hline S-ENSO6Z5-OW & $7 / 4 / 02$ & $<0.05$ & 0 & 0.05 & 0.27 & 1 & 1 & 0 & & & 1 & 0.5 & 8.4 \\
\hline S-ENSO9ZO-OW DUP & $7 / 4 / 02$ & $<0.01$ & 0 & 0.05 & 0.083 & 2 & 5 & 0 & $<0.05$ & 0 & 1 & 0.5 & 8.1 \\
\hline S-ENSO9Z0-OW RTN & $7 / 4 / 02$ & $<0.05$ & 0 & 0.05 & 0.28 & 1 & 1 & 0 & & & 1 & 0.5 & 8.2 \\
\hline Maximum discharge valu & $\mathrm{mg} / \mathrm{L}$ & & & & & & NA & & & & & NA & \\
\hline
\end{tabular}

\begin{tabular}{|c|c|c|c|c|c|c|c|c|c|c|c|c|c|}
\hline \multirow{2}{*}{ GENMIN } & \multirow[t]{2}{*}{$\mathrm{mg} / \mathrm{L}$} & \multicolumn{2}{|c|}{ Manganese } & \multicolumn{2}{|c|}{ Nickel } & \multicolumn{2}{|c|}{$\begin{array}{c}\text { Nitrate } \\
\text { (as N) }\end{array}$} & \multicolumn{2}{|c|}{$\begin{array}{c}\text { Nitrate } \\
\text { (as } \mathrm{NO}_{3} \text { ) }\end{array}$} & \multicolumn{2}{|c|}{$\begin{array}{c}\text { Nitrate plus } \\
\text { Nitrate } \\
\text { (as N) } \\
\end{array}$} & \multicolumn{2}{|c|}{$\begin{array}{c}\text { Nitrate } \\
\text { (as N) }\end{array}$} \\
\hline & & LOS & CALC & LOS & CALC & LOS & CALC & LOS & CALC & LOS & CALC & LOS & CALC \\
\hline S-DISCHGE-OW & $7 / 4 / 02$ & \multirow{4}{*}{$<0.01$} & \multirow{4}{*}{0} & $<0.1$ & 0 & 0.1 & 1 & 0.1 & 4.4 & \multirow{4}{*}{0.1} & \multirow{4}{*}{1.5} & $<0.1$ & 0 \\
\hline S-ENSO6Z5-OW & $7 / 4 / 02$ & & & $<0.1$ & 0 & 0.1 & 7.7 & 0.1 & 34 & & & $<0.1$ & 0 \\
\hline S-ENSO9Z0-OW DUP & $7 / 4 / 02$ & & & $<0.05$ & 0 & 0.1 & 1.5 & 0.4 & 6.6 & & & $<0.02$ & 0 \\
\hline S-ENSO9Z0-OW RTN & $7 / 4 / 02$ & & & $<0.1$ & 0 & 0.1 & 4 & 0.1 & 18 & & & $<0.1$ & 0 \\
\hline \multicolumn{2}{|c|}{ Maximum discharge values* $\mathrm{mg} / \mathrm{L}$} & \multicolumn{2}{|c|}{1.0} & \multicolumn{2}{|c|}{0.5} & \multicolumn{2}{|c|}{ NA } & \multicolumn{2}{|c|}{ NA } & \multicolumn{2}{|c|}{ NA } & \multicolumn{2}{|c|}{ NA } \\
\hline
\end{tabular}

\begin{tabular}{|c|c|c|c|c|c|c|c|c|c|c|c|c|}
\hline \multirow[t]{2}{*}{ GENMIN } & \multirow[t]{2}{*}{$\mathrm{mg} / \mathrm{L}$} & \multicolumn{3}{|c|}{ Ortho Phosphate } & \multicolumn{2}{|c|}{ pH (Units) } & \multicolumn{3}{|c|}{ Potassium } & \multicolumn{3}{|c|}{ Sodium } \\
\hline & & LOS & CAL & & LOS C & & dilution & LOS & CALC & dilution & LOS & CALC \\
\hline S-DISCHGE-OW & $7 / 4 / 02$ & 0.02 & 0.6 & & 0.1 & & 10 & 10 & 450 & 100 & 100 & 6600 \\
\hline S-ENSO6Z5-OW & $7 / 4 / 02$ & $<0.02$ & 0 & & 0.1 & & 1 & 1 & 2 & 1 & 1 & 41 \\
\hline S-ENSO9ZO-OW DUP & $7 / 4 / 02$ & $<0.05$ & 0 & & 0 & & 1 & 1 & 1.1 & 1 & 1 & 38 \\
\hline \multirow[t]{2}{*}{ S-ENSO9ZO-OW RTN } & $7 / 4 / 02$ & $<0.02$ & 0 & & 0.1 & 1 & 1 & 1 & 2 & 1 & 1 & 41 \\
\hline & & \multicolumn{3}{|c|}{ NA } & \multicolumn{2}{|c|}{$6.5-8.5$} & \multicolumn{3}{|c|}{ NA } & \multicolumn{3}{|c|}{ NA } \\
\hline \multirow[t]{2}{*}{ GENMIN } & \multirow[t]{2}{*}{$\mathrm{mg} / \mathrm{L}$} & \multicolumn{3}{|c|}{$\begin{array}{c}\begin{array}{c}\text { Specific Conductance } \\
(\mu \mathrm{mhos} / \mathrm{cm})\end{array} \\
\end{array}$} & \multicolumn{3}{|c|}{ Sulfate } & \multicolumn{2}{|c|}{ Surfactants } & \multicolumn{3}{|c|}{$\begin{array}{l}\text { Total Alkalinity } \\
\left(\text { as } \mathrm{CaCO}_{3}\right)\end{array}$} \\
\hline & & dilution & LOS & CALC & dilution & LOS & CALC & LOS & CALC & dilution & LOS & CALC \\
\hline S-DISCHGE-OW & $7 / 4 / 02$ & 10 & 100 & 40000 & 100 & 100 & 1800 & $<0.5$ & 0 & 1 & 1 & 150 \\
\hline S-ENSO6Z5-OW & $7 / 4 / 02$ & 10 & 100 & 1000 & 1 & 1 & 7 & $<0.5$ & 0 & 1 & 1 & 350 \\
\hline S-ENSO9Z0-OW DUP & $7 / 4 / 02$ & 1 & 1 & 671 & 1 & 1 & 6.1 & $<0.5$ & 0 & 2 & 5 & 280 \\
\hline S-ENSO9ZO-OW RTN & $7 / 4 / 02$ & 1 & 10 & 680 & 1 & 1 & 8 & $<0.5$ & 0 & 1 & 1 & 270 \\
\hline \multicolumn{2}{|c|}{ Maximum discharge values ${ }^{*} \mathrm{mg} / \mathrm{L}$} & \multicolumn{3}{|c|}{$2700^{*}$} & \multicolumn{3}{|c|}{ NA } & \multicolumn{2}{|c|}{ NA } & \multicolumn{3}{|c|}{ NA } \\
\hline
\end{tabular}


Table 8. General minerals analysis in water (continued)

\begin{tabular}{|c|c|c|c|c|c|c|c|c|c|c|c|c|c|c|}
\hline \multirow[t]{2}{*}{ GENMIN } & \multirow[t]{2}{*}{$\mathrm{mg} / \mathrm{L}$} & \multicolumn{3}{|c|}{$\begin{array}{l}\text { Total dissolved solids } \\
\text { (TDS) }\end{array}$} & \multicolumn{2}{|c|}{$\begin{array}{l}\text { Total Hardness } \\
\text { (as } \mathrm{CaCO}_{3} \text { ) }\end{array}$} & \multicolumn{2}{|c|}{$\begin{array}{l}\text { Total Kjeldahl } \\
\text { Nitrogen }\end{array}$} & \multicolumn{2}{|c|}{$\begin{array}{c}\text { Total } \\
\text { Phosphorus } \\
\text { (as P) }\end{array}$} & \multicolumn{2}{|c|}{$\begin{array}{c}\text { Total } \\
\text { Phosphorus } \\
\text { (as } \mathrm{PO}_{4} \text { ) }\end{array}$} & \multicolumn{2}{|c|}{ Zinc } \\
\hline & & dilution & LOS & CALC & LOS & CALC & LOS & CALC & LOS & CALC & LOS & CALC & LOS & CALC \\
\hline S-DISCHGE-OW & $7 / 4 / 02$ & 2 & 2 & 23000 & 1 & 4300 & $<0.2$ & 0.4 & & & 0.05 & 0.11 & $<0.05$ & 0 \\
\hline S-ENSO6Z5-OW & $7 / 4 / 02$ & 1 & 1 & 510 & 1 & 360 & $<0.2$ & 0 & & & $<0.05$ & 0 & $<0.05$ & 0 \\
\hline S-ENSO9ZO-OW DUP & $7 / 4 / 02$ & 2 & 20 & 306 & 5 & 248 & $<0.2$ & 0 & $<0.05$ & 0 & & & 0.05 & 0.36 \\
\hline S-ENSO9ZO-OW RTN & $7 / 4 / 02$ & 1 & 1 & 380 & 1 & 270 & $<0.2$ & 0 & & & 0.05 & 0.28 & 0.05 & 0.77 \\
\hline Maximum discharge valt & $\mathrm{mg} / \mathrm{L}$ & & NA & & & IA & & & & .0 & & & 5 & 0 \\
\hline
\end{tabular}

Note:

* Maximum value for direct discharge (Morocco Ministry of Environment). http://www.minenv.gov.ma/projets/fodep/TDRFOD2.htm 


\section{Table 9. Semivolatile organic compounds}

\begin{tabular}{|c|c|c|c|c|c|c|c|c|c|c|c|c|c|}
\hline \multirow[t]{2}{*}{$\begin{array}{c}\text { EPA Method } 525.2 \\
\text { E525 } \\
(\text { All dilutions = 1) }\end{array}$} & & \multicolumn{2}{|c|}{ Benzo(a)pyrene } & \multicolumn{2}{|c|}{ Endrin } & \multicolumn{2}{|c|}{ Heptachlor } & \multicolumn{2}{|c|}{$\begin{array}{l}\text { Heptachlor } \\
\text { epoxide }\end{array}$} & \multicolumn{2}{|c|}{$\begin{array}{l}\text { Hexachloro- } \\
\text { benzene }\end{array}$} & \multicolumn{2}{|c|}{$\begin{array}{c}\text { Hexachloro- } \\
\text { cyclopentadiene }\end{array}$} \\
\hline & & LOS & CALC & LOS & CALC & LOS & CALC & LOS & CALC & LOS & CALC & LOS & CALC \\
\hline ENS06Z5-OW & $7 / 4 / 02$ & $<0.5$ & 0 & $<2$ & 0 & $<0.5$ & 0 & $<0.5$ & 0 & $<1$ & 0 & $<3$ & 0 \\
\hline ENS09Z0-OW & $7 / 4 / 02$ & $<0.5$ & 0 & $<2$ & 0 & $<0.5$ & 0 & $<0.5$ & 0 & $<1$ & 0 & $<3$ & 0 \\
\hline DISCHARGE-OW & $7 / 4 / 02$ & $<0.5$ & 0 & $<2$ & 0 & $<0.5$ & 0 & $<0.5$ & 0 & $<1$ & 0 & $<3$ & 0 \\
\hline QA-WATER-OW & $7 / 4 / 02$ & $<0.1$ & 0 & & & & & & & & & & \\
\hline *US-EPA MCL & & & & & 2 & 0 & & & 2 & & 1 & & \\
\hline
\end{tabular}

EPA Method 525.2 E525

(All dilutions = 1 )

ENS06Z5-OW

ENS09Z0-OW

DISCHARGE-OW

QA-WATER-OW

*US-EPA MCL

\begin{tabular}{|c|c|c|c|c|c|c|c|c|c|c|c|}
\hline \multicolumn{2}{|c|}{ Pentachlorophenol } & \multicolumn{2}{|c|}{ Alachlor } & \multicolumn{2}{|c|}{ Atrazine } & \multicolumn{2}{|c|}{ Chlordane } & \multicolumn{2}{|c|}{$\begin{array}{c}\text { Di (2-ethylhexyl) } \\
\text { adipate }\end{array}$} & \multicolumn{2}{|c|}{ Methoxychlor } \\
\hline LOS & CALC & LOS & CALC & LOS & CALC & LOS & CALC & LOS & CALC & LOS & CALC \\
\hline$<1$ & 0 & $<0.5$ & 0 & $<0.5$ & 0 & $<2$ & 0 & $<1$ & 0 & $<0.7$ & 0 \\
\hline$<1$ & 0 & $<0.5$ & 0 & $<0.5$ & 0 & $<2$ & 0 & $<1$ & 0 & $<0.7$ & 0 \\
\hline \multirow{2}{*}{\multicolumn{2}{|c|}{$<1$}} & $<0.5$ & 0 & $<0.5$ & 0 & $<2$ & 0 & $<1$ & 0 & $<0.7$ & 0 \\
\hline & & 1 & 0 & $<1$ & 0 & & & & & & \\
\hline \multicolumn{2}{|c|}{1} & \multicolumn{2}{|c|}{2} & \multicolumn{2}{|c|}{3} & \multicolumn{2}{|c|}{2} & \multicolumn{2}{|c|}{400} & \multicolumn{2}{|c|}{40} \\
\hline
\end{tabular}

\section{EPA Method 525.2 \\ E525 \\ (All dilutions $=1$ )}

ENS06Z5-OW

ENS09Z0-OW

DISCHARGE-OW

QA-WATER-OW

*US-EPA MCL

\begin{tabular}{|c|c|c|c|c|c|}
\hline \multicolumn{2}{|c|}{ РСВ } & \multicolumn{2}{|c|}{ Simazine } & \multicolumn{2}{|c|}{ Toxaphene } \\
\hline LOS & CALC & LOS & CALC & LOS & CALC \\
\hline 0.5 & 0 & 0.5 & 0 & 5 & 0 \\
\hline 0.5 & 0 & 0.5 & 0 & 5 & 0 \\
\hline \multirow[t]{2}{*}{0.5} & 0 & 0.5 & 0 & 5 & 0 \\
\hline & & 1 & 0 & & \\
\hline \multicolumn{2}{|c|}{0.5} & \multicolumn{2}{|c|}{4} & \multicolumn{2}{|c|}{3} \\
\hline
\end{tabular}

Notes:

All 525.2 water analyses performed by BC Laboratories Inc., except sample "QA-WATER-OW" which was analyzed by Caltest Laboratories.

All values presented are in $\mu \mathrm{g} / \mathrm{L}$.

* US EPA Maximum Contaminant Level (MCL) for National Primary Drinking Water Regulations.

Go to: http://www.epa.gov. In the "Search" window, type "MCL." Click on "Go." Under "Title and Summary" click on \#2, List of Drinking Water Contaminants and MCLs. 


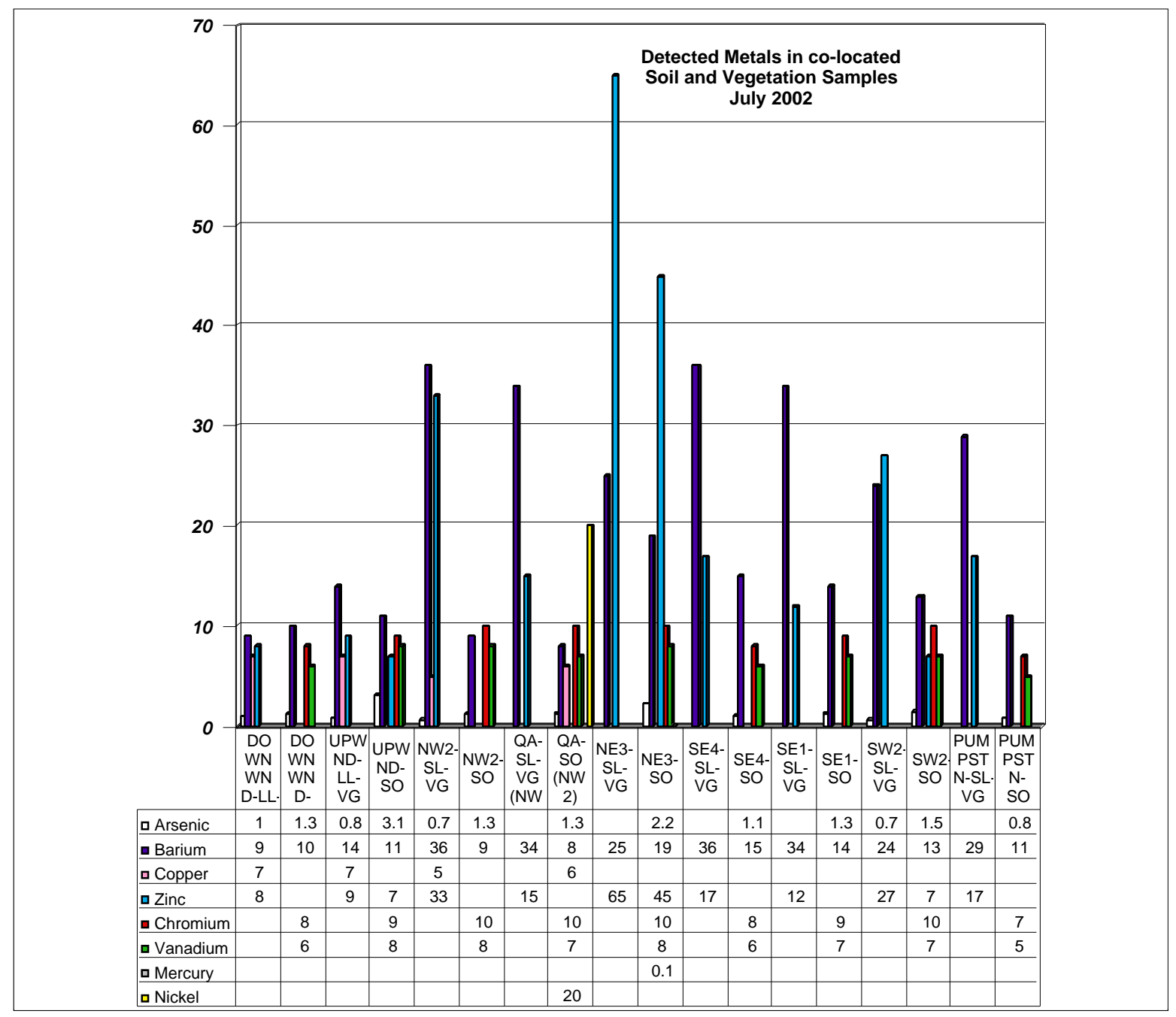

Chart 1. Metals in short-lived and long-lived vegetation and soils co-located samples 


\section{Attachment 1:}

\section{Appendix A of EPA 540/R95/128, Soil Screening Guidance:}

\section{Technical Background Document, May 1996}




\section{APPENDIX A}

\section{Generic SSLs}

Table A-1 provides generic SSLs for 110 chemicals. Generic SSLs are derived using default values in the standardized equations presented in Part 2 of this document. The default values (listed in Table A-2) are conservative and are likely to be protective for the majority of site conditions across the nation.

However, the generic SSLs are not necessarily protective of all known human exposure pathways, reasonable land uses, or ecological threats. Thus, before applying generic SSLs at a site, it is extremely important to compare the conceptual site model (see the User's Guide) with the assumptions behind the SSLs to ensure that the site conditions and exposure pathways match those used to develop generic SSLs (see Parts 1 and 2 and Table A-2). If this comparison indicates that the site is more complex than the SSL scenario, or that there are significant exposure pathways not accounted for by the SSLs, then generic SSLs are not sufficient for a full evaluation of the site. A more detailed site-specific approach will be necessary to evaluate the additional pathways or site conditions.

Generic SSLs are presented separately for major pathways of concern in both surface and subsurface soils. The first column to the right of the chemical name presents levels based on direct ingestion of soil and the second column presents levels based on inhalation. As discussed in the User's Guide, the fugitive dust pathway may be of concern for certain metals but does not appear to be of concern for organic compounds. Therefore, SSLs for the fugitive dust pathway are only presented for inorganic compounds. Except for mercury, no SSLs for the inhalation of volatiles pathway are provided for inorganic compounds because these chemicals are not volatile.

The user should note that several of the generic SSLs for the inhalation of volatiles pathway are determined by the soil saturation concentration $\left(\mathrm{C}_{\text {sat }}\right)$, which is used to address and screen the potential presence of nonaqueous phase liquids (NAPLs). As explained in Section 2.4.4, for compounds that are liquid at ambient soil temperature, concentrations above $\mathrm{C}_{\text {sat }}$ indicate a potential for free-phase liquid contamination to be present and the need for additional investigation.

The third column presents generic SSL values for the migration to ground water pathway developed using a default DAF (dilution-attenuation factor) of 20 to account for natural processes that reduce contaminant concentrations in the subsurface (see Section 2.5.6). SSLs in Table A-1 are rounded to two significant figures except for values less than 10, which are rounded to one significant figure. Note that the 20 DAF values in Table A-1 are not exactly 20 times the 1 DAF values because each SSL is calculated independently in both the $20 \mathrm{DAF}$ and $1 \mathrm{DAF}$ columns, with the final value presented according to the aforementioned rounding conventions.

The fourth column contains the generic SSLs for the migration to ground water pathway developed assuming no dilution or attenuation between the source and the receptor well (i.e., a DAF of 1). These values can be used at sites where little or no dilution or attenuation of soil leachate concentrations is expected at a site (e.g., sites with shallow water tables, fractured media, karst topography, or source size greater than 30 acres).

Generally, if an SSL is not exceeded for a pathway of concern, the user may eliminate the pathway or areas of the site from further investigation. If more than one exposure pathway is of concern, the lowest SSL should be used. 
Table A-1. Generic SSLs a

\begin{tabular}{|c|c|c|c|c|c|}
\hline \multirow{2}{*}{$\begin{array}{l}\text { Organics } \\
\text { CAS No. }\end{array}$} & \multirow[b]{2}{*}{ Compound } & \multirow[b]{2}{*}{$\begin{array}{c}\text { Ingestion } \\
\text { (mg/kg) }\end{array}$} & \multirow[b]{2}{*}{$\begin{array}{c}\text { Inhalation } \\
\text { volatiles } \\
\text { (mg/kg) }\end{array}$} & \multicolumn{2}{|c|}{ Migration to ground water } \\
\hline & & & & $\begin{array}{l}20 \mathrm{DAF} \\
(\mathrm{mg} / \mathrm{kg})\end{array}$ & $\begin{array}{c}1 \text { DAF } \\
(\mathrm{mg} / \mathrm{kg})\end{array}$ \\
\hline $83-32-9$ & Acenaphthene & 4,700 & $-a c$ & $570 \mathrm{~b}$ & $29 \mathrm{~b}$ \\
\hline $67-64-1$ & Acetone & $7,800 \mathrm{~b}$ & $1.0 E+05 d$ & $16^{b}$ & $0.8 \mathrm{~b}$ \\
\hline $309-00-2$ & Aldrin & $0.04^{e}$ & $3^{e}$ & $0.5^{\ominus}$ & $0.02 \theta$ \\
\hline $120-12-7$ & Anthracene & $23,000 \mathrm{~b}$ & $--\mathrm{c}$ & $12,000 \mathrm{~b}$ & $590 \mathrm{~b}$ \\
\hline $56-55-3$ & Benz(a)anthracene & $0.9^{\theta}$ & -.. c & $2^{e}$ & 0.08 e,f \\
\hline $71-43-2$ & Benzene & $22 e$ & $0.8^{e}$ & 0.03 & $0.002 f$ \\
\hline $205-99-2$ & Benzo(b)fluoranthene & $0.9^{e}$ & -.. c & $5^{e}$ & $0.2^{e, f}$ \\
\hline $207-08-9$ & Benzo $(k)$ fluoranthene & $9^{e}$ & $\ldots c$ & $49 e$ & $2 e$ \\
\hline $65-85-0$ & Benzoic acid & $3.1 E+05 b$ & -- c & $400 \mathrm{~b}, \mathrm{i}$ & $20 \mathrm{~b}, \mathrm{i}$ \\
\hline $50-32-8$ & Benzo(a)pyrene & $0.09 \theta, f$ & --. c & 8 & 0.4 \\
\hline $111-44-4$ & Bis(2-chloroethyl)ether & $0.6^{e}$ & $0.2^{e, f}$ & 0.0004 e,f & $2 E-05$ e,f \\
\hline $117-81-7$ & Bis(2-ethylhexyl)phthalate & $46^{e}$ & $31,000 \mathrm{~d}$ & 3,600 & 180 \\
\hline $75-27-4$ & Bromodichloromethane & $10^{e}$ & $3,000 d$ & 0.6 & 0.03 \\
\hline $75-25-2$ & Bromoform & $81 \theta$ & $53 e$ & 0.8 & 0.04 \\
\hline $71-36-3$ & Butanol & 7,800 b & $10,000 \mathrm{~d}$ & $17^{b}$ & $0.9^{b}$ \\
\hline $85-68-7$ & Butyl benzyl phthalate & $16,000^{b}$ & $930^{d}$ & $930^{d}$ & $810 b$ \\
\hline $86-74-8$ & Carbazole & $32 \mathrm{e}$ & $--c^{c}$ & $0.6^{e}$ & 0.03 e,f \\
\hline $75-15-0$ & Carbon disulfide & $7,800 \mathrm{~b}$ & $720^{d}$ & $32 \mathrm{~b}$ & $2 b$ \\
\hline $56-23-5$ & Carbon tetrachloride & $5^{e}$ & $0.3^{e}$ & 0.07 & $0.003^{f}$ \\
\hline $57-74-9$ & Chlordane & $0.5^{e}$ & $20 e$ & 10 & 0.5 \\
\hline $106-47-8$ & $p$-Chloroaniline & $310^{b}$ & $\ldots c$ & $0.7 \mathrm{~b}$ & $0.03 b, f$ \\
\hline $108-90-7$ & Chlorobenzene & $1,600^{b}$ & $130 \mathrm{~b}$ & 1 & 0.07 \\
\hline $124-48-1$ & Chlorodibromomethane & $8^{e}$ & $1,300 \mathrm{~d}$ & 0.4 & 0.02 \\
\hline $67-66-3$ & Chloroform & $100^{e}$ & $0.3^{e}$ & 0.6 & 0.03 \\
\hline $95-57-8$ & 2-Chlorophenol & $390 \mathrm{~b}$ & $53,000 \mathrm{~d}$ & $4 b, i$ & $0.2 b, f, i$ \\
\hline $218-01-9$ & Chrysene & $88^{e}$ & -.- c & $160^{e}$ & $8^{e}$ \\
\hline $72-54-8$ & DDD & $3^{e}$ & --. c & $16 e$ & $0.8^{\theta}$ \\
\hline $72-55-9$ & DDE & $2^{e}$ & $\ldots c$ & 54 e & $3^{e}$ \\
\hline $50-29-3$ & DDT & $2^{e}$ & $\ldots g$ & 32 e & $2^{\theta}$ \\
\hline $53-70-3$ & Dibenz $(a, h)$ anthracene & $0.09 e, f$ & $\ldots c$ & $2 \theta$ & 0.08 e,f \\
\hline $84-74-2$ & Di-n-butyl phthalate & $7,800^{b}$ & $2,300 d$ & $2,300 d$ & $270 \mathrm{~b}$ \\
\hline $95-50-1$ & 1,2-Dichlorobenzene & $7,000 \mathrm{~b}$ & $560^{d}$ & 17 & 0.9 \\
\hline $106-46-7$ & 1,4-Dichlorobenzene & $27^{e}$ & $\ldots g$ & 2 & $0.1^{f}$ \\
\hline $91-94-1$ & 3,3-Dichlorobenzidine & $1^{e}$ & -.. c & $0.007^{e, t}$ & 0.0003 e,f \\
\hline $75-34-3$ & 1,1-Dichloroethane & $7,800^{b}$ & $1,300 b$ & $23^{b}$ & $1 \mathrm{~b}$ \\
\hline $107-06-2$ & 1,2-Dichloroethane & $7^{e}$ & $0.4^{e}$ & 0.02 & $0.001 f$ \\
\hline $75-35-4$ & 1,1-Dichloroethylene & $1^{e}$ & $0.07^{e}$ & 0.06 & $0.003^{f}$ \\
\hline $156-59-2$ & cis-1,2-Dichloroethylene & $780^{b}$ & $1,200^{d}$ & 0.4 & 0.02 \\
\hline $156-60-5$ & trans-1,2-Dichloroethylene & $1,600 \mathrm{~b}$ & $3,100 \mathrm{~d}$ & 0.7 & 0.03 \\
\hline $120-83-2$ & 2,4-Dichlorophenol & $230^{b}$ & $---c$ & $1 b, i$ & $0.05 b, f, i$ \\
\hline
\end{tabular}


Table A-1 (continued)

\begin{tabular}{|c|c|c|c|c|c|}
\hline \multirow{2}{*}{$\begin{array}{l}\text { Organics } \\
\text { CAS No. }\end{array}$} & \multirow[b]{2}{*}{ Compound } & & \multirow[b]{2}{*}{$\begin{array}{c}\text { Inhalation } \\
\text { volatiles } \\
\text { (mg/kg) }\end{array}$} & \multicolumn{2}{|c|}{ Migration to ground water } \\
\hline & & $\begin{array}{c}\text { Ingestion } \\
(\mathbf{m g} / \mathbf{k g}) \\
\end{array}$ & & $\begin{array}{l}20 \text { DAF } \\
(\mathrm{mg} / \mathrm{kg})\end{array}$ & $\begin{array}{c}1 \text { DAF } \\
(\mathrm{mg} / \mathrm{kg})\end{array}$ \\
\hline $78-87-5$ & 1,2-Dichloropropane & $9^{e}$ & $15 \mathrm{~b}$ & 0.03 & $0.001^{1}$ \\
\hline $542-75-6$ & 1,3-Dichloropropene & $4^{e}$ & $0.1 e$ & 0.004 e & $0.0002 e$ \\
\hline $60-57-1$ & Dieldrin & $0.04^{e}$ & $1 e$ & $0.004^{e}$ & 0.0002 e,f \\
\hline $84-66-2$ & Diethylphthalate & $63,000 \mathrm{~b}$ & $2,000 d$ & $470 \mathrm{~b}$ & $23^{b}$ \\
\hline $105-67-9$ & 2,4-Dimethylphenol & $1,600 \mathrm{~b}$ & --. $\mathrm{c}$ & $9 \mathrm{~b}$ & $0.4^{b}$ \\
\hline $51-28-5$ & 2,4-Dinitrophenol & $160 \mathrm{~b}$ & $\ldots \mathrm{c}$ & $0.3 b, f, i$ & $0.01 b, f, i$ \\
\hline $121-14-2$ & 2,4-Dinitrotoluene & $0.9^{e}$ & $-\ldots \mathrm{c}$ & 0.0008 e.f & $4 E-05$ e,f \\
\hline $606-20-2$ & 2,6-Dinitrotoluene & $0.9^{\theta}$ & -.- c & 0.0007 e,f & $3 E-05$ e,f \\
\hline $117-84-0$ & Di-n-octyl phthalate & $1,600 \mathrm{~b}$ & $10,000 d$ & $10,000 \mathrm{~d}$ & $10,000 d$ \\
\hline $115-29-7$ & Endosulfan & $470 b$ & -.. c & $18 b$ & $0.9 \mathrm{~b}$ \\
\hline $72-20-8$ & Endrin & $23 b$ & -.. c & 1 & 0.05 \\
\hline $100-41-4$ & Ethylbenzene & $7,800 \mathrm{~b}$ & $400 d$ & 13 & 0.7 \\
\hline $206-44-0$ & Fluoranthene & $3,100 \mathrm{~b}$ & -.. c & $4,300 \mathrm{~b}$ & $210^{b}$ \\
\hline $86-73-7$ & Fluorene & $3,100 \mathrm{~b}$ & $\ldots$ & $560 \mathrm{~b}$ & $28 \mathrm{~b}$ \\
\hline $76-44-8$ & Heptachlor & $0.1^{e}$ & $0.1^{e}$ & 23 & 1 \\
\hline $1024-57-3$ & Heptachlor epoxide & $0.07^{\theta}$ & $5^{e}$ & 0.7 & 0.03 \\
\hline $118-74-1$ & Hexachlorobenzene & $0.4^{e}$ & 10 & 2 & $0.1^{f}$ \\
\hline $87-68-3$ & Hexachloro-1,3-butadiene & $8^{e}$ & $8^{e}$ & 2 & $0.1 f$ \\
\hline $319-84-6$ & $\alpha-\mathrm{HCH}(\alpha-\mathrm{BHC})$ & $0.1 e$ & $0.8^{e}$ & 0.0005 e,f & $3 E-05$ e,f \\
\hline $319-85-7$ & $\beta-\mathrm{HCH}(\beta-\mathrm{BHC})$ & $0.4^{e}$ & $---g$ & $0.003^{\theta}$ & 0.0001 e,f \\
\hline $58-89-9$ & $\gamma-\mathrm{HCH}$ (Lindane) & $0.5^{e}$ & -- c & 0.009 & $0.0005^{f}$ \\
\hline $77-47-4$ & Hexachlorocyclopentadiene & $550 \mathrm{~b}$ & $10 b$ & 400 & 20 \\
\hline $67-72-1$ & Hexachloroethane & $46 e$ & $55^{e}$ & $0.5 e$ & $0.02 e, f$ \\
\hline $193-39-5$ & Indeno(1,2,3-cd)pyrene & $0.9^{\mathrm{e}}$ & --- c & $14^{e}$ & $0.7 e$ \\
\hline $78-59-1$ & Isophorone & $670 e$ & $4,600 d$ & $0.5 e$ & 0.03 e,f \\
\hline $7439-97-6$ & Mercury & $23 b, 1$ & $10 b, i$ & $2 i$ & $0.1 i$ \\
\hline $72-43-5$ & Methoxychlor & $390 \mathrm{~b}$ & -.. c & 160 & 8 \\
\hline $74-83-9$ & Methyl bromide & $110^{b}$ & $10 \mathrm{~b}$ & $0.2^{b}$ & $0.01 b, f$ \\
\hline $75-09-2$ & Methylene chloride & 85 e & $13 \theta$ & $0.02^{e}$ & 0.001 e,f \\
\hline $95-48-7$ & 2-Methylphenol & $3,900 \mathrm{~b}$ & $\ldots c$ & $15^{b}$ & $0.8 \mathrm{~b}$ \\
\hline $91-20-3$ & Naphthalene & $3,100 \mathrm{~b}$ & $---\mathrm{c}$ & $84 \mathrm{~b}$ & $4 \mathrm{~b}$ \\
\hline $98-95-3$ & Nitrobenzene & $39 \mathrm{~b}$ & $92 \mathrm{~b}$ & $0.1 b, f$ & $0.007 b, f$ \\
\hline $86-30-6$ & N-Nitrosodiphenylamine & $130 e$ & $---c$ & $1 e$ & $0.06 \theta, f$ \\
\hline $621-64-7$ & $N$-Nitrosodi- $n$-propylamine & 0.09 e.f & $-\mathrm{c}^{\mathrm{c}}$ & $5 E-05$ e,f & $2 E-06 e, f$ \\
\hline $1336-36-3$ & PCBs & $1^{h}$ & $---h$ & $\ldots h$ & $\ldots h$ \\
\hline $87-86-5$ & Pentachlorophenol & $3 e, j$ &.$-- c$ & $0.03^{f, i}$ & $0.001 \mathrm{f,i}$ \\
\hline $108-95-2$ & Phenol & $47,000 \mathrm{~b}$ &.$-- c$ & $100 \mathrm{~b}$ & $5 \mathrm{~b}$ \\
\hline $129-00-0$ & Pyrene & $2,300 \mathrm{~b}$ & $\ldots c$ & $4,200 \mathrm{~b}$ & $210^{b}$ \\
\hline $100-42-5$ & Styrene & $16,000 \mathrm{~b}$ & $1,500 \mathrm{~d}$ & 4 & 0.2 \\
\hline $79-34-5$ & 1,1,2,2-Tetrachloroethane & $3 e$ & $0.6^{e}$ & $0.003 e, f$ & 0.0002 e.f \\
\hline
\end{tabular}


Table A-1 (continued)

\begin{tabular}{|c|c|c|c|c|c|}
\hline \multirow{2}{*}{$\begin{array}{l}\text { Organics } \\
\text { CAS No. }\end{array}$} & \multirow[b]{2}{*}{ Compound } & \multirow[b]{2}{*}{$\begin{array}{c}\text { Ingestion } \\
\text { (mg/kg) }\end{array}$} & \multirow[b]{2}{*}{$\begin{array}{c}\text { Inhalation } \\
\text { volatiles } \\
(\mathrm{mg} / \mathrm{kg})\end{array}$} & \multicolumn{2}{|c|}{ Migration to ground water } \\
\hline & & & & $\begin{array}{l}20 \text { DAF } \\
(\mathrm{mg} / \mathrm{kg})\end{array}$ & $\begin{array}{c}1 \mathrm{DAF} \\
(\mathrm{mg} / \mathrm{kg})\end{array}$ \\
\hline $127-18-4$ & Tetrachloroethylene & $12^{\theta}$ & $11^{\theta}$ & 0.06 & $0.003^{1}$ \\
\hline $108-88-3$ & Toluene & $16,000 \mathrm{~b}$ & $650^{d}$ & 12 & 0.6 \\
\hline $8001-35-2$ & Toxaphene & $0.6^{e}$ & $89^{\theta}$ & 31 & 2 \\
\hline $120-82-1$ & 1,2,4-Trichlorobenzene & $780 b$ & $3,200 d$ & 5 & $0.3^{f}$ \\
\hline $71-55-6$ & 1,1,1-Trichloroethane & $---c$ & $1,200^{d}$ & 2 & 0.1 \\
\hline $79-00-5$ & 1,1,2-Trichloroethane & $11 e$ & $1 e$ & 0.02 & $0.0009 f$ \\
\hline $79-01-6$ & Trichloroethylene & $58 \theta$ & $5^{e}$ & 0.06 & $0.003^{f}$ \\
\hline $95-95-4$ & 2,4,5-Trichlorophenol & $7,800^{b}$ & $---c$ & 270 b,i & $14 b, i$ \\
\hline $88-06-2$ & 2,4,6-Trichlorophenol & 58 e & $200^{\theta}$ & 0.2 e.f.i & $0.008^{e, f, i}$ \\
\hline $108-05-4$ & Vinyl acetate & $78,000 b$ & $1,000 \mathrm{~b}$ & $170^{b}$ & $8^{b}$ \\
\hline $75-01-4$ & Vinyl chloride & $0.3^{e}$ & $0.03^{e}$ & $0.01^{f}$ & 0.0007 \\
\hline $108-38-3$ & $m$-Xylene & $1.6 E+05 b$ & $420^{d}$ & 210 & 10 \\
\hline $95-47-6$ & o-Xylene & $1.6 \mathrm{E}+05^{b}$ & $410^{d}$ & 190 & 9 \\
\hline $106-42-3$ & $p$-Xylene & $1.6 \mathrm{E}+05^{\mathrm{b}}$ & $460^{d}$ & 200 & 10 \\
\hline
\end{tabular}




\section{Table A-1 (continued)}

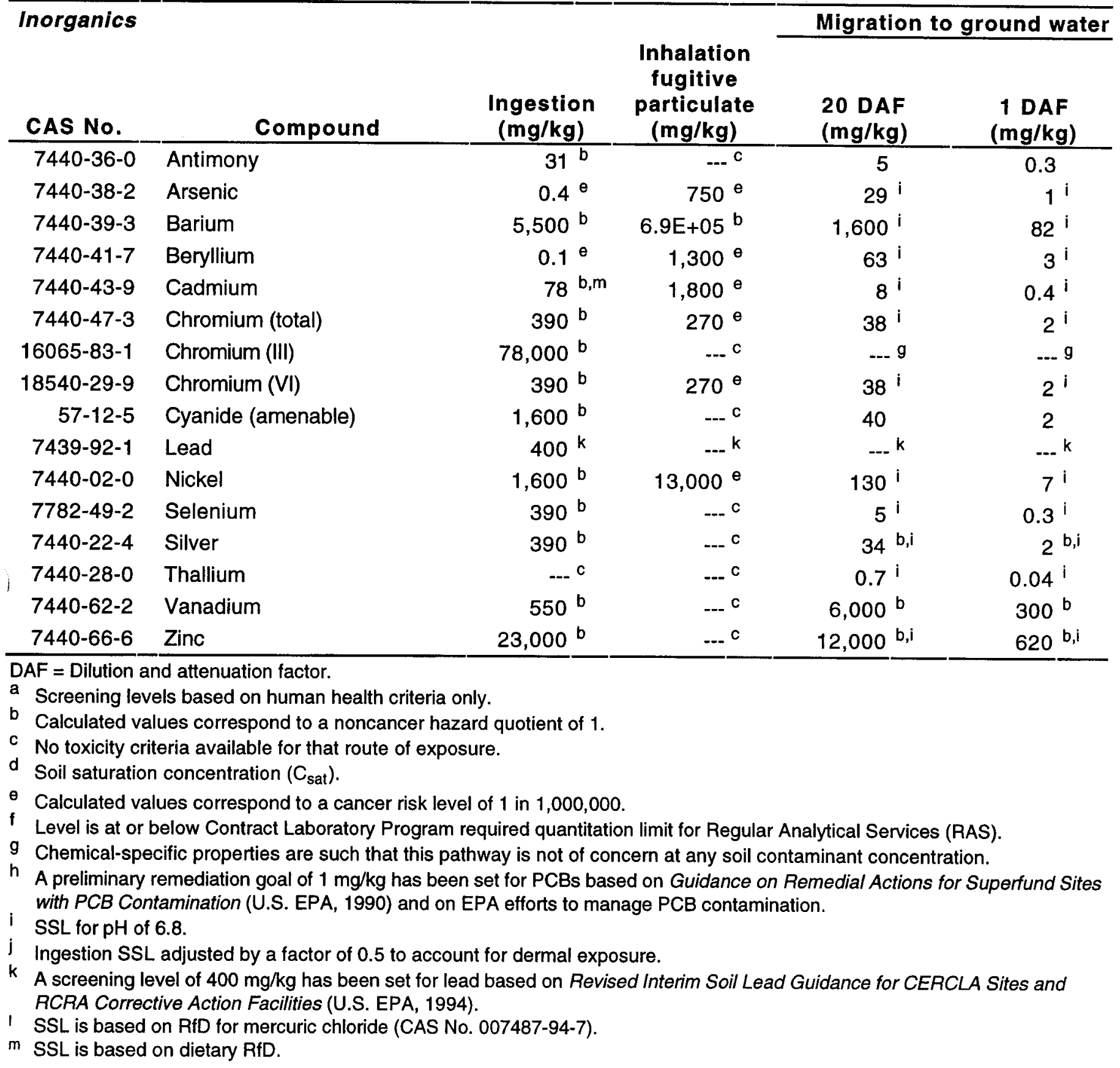

